\section{Phenotypic Diversity for Root Traits and Identification of Superior Germplasm for Root Breeding in Watermelon}

\author{
Dennis N. Katuuramu and W. Patrick Wechter \\ U.S. Department of Agriculture, Agricultural Research Services, U.S. \\ Vegetable Laboratory, 2700 Savannah Highway, Charleston, SC 29414
}

\section{Marcellus L. Washington, Matthew Horry, and Matthew A. Cutulle} Vegetable Weed Science, Horticulture Program Team, Plant and Environmental Sciences Department, Coastal Research and Education Center, Clemson University, Charleston, SC 29414

\section{Robert L. Jarret}

U.S. Department of Agriculture, Agricultural Research Services, Plant Genetic Resources Conservation Unit, 1109 Experiment Street, Griffin, GA 30223

\section{Amnon Levi \\ U.S. Department of Agriculture, Agricultural Research Services, U.S. Vegetable Laboratory, 2700 Savannah Highway, Charleston, SC 29414}

Additional index words. biotic and abiotic stresses, germplasm accessions, watermelon root breeding, WinRHIZO

\begin{abstract}
Root traits are an important component for productive plant performance. Roots offer immediate absorptive surfaces for water and nutrient acquisition and are thus critical to crop growth and response to biotic and abiotic stresses. In addition, roots can provide the first line of defense against soilborne pathogens. Watermelon crop performance is often challenged by inclement weather and environmental factors. A resilient root system can support the watermelon crop's performance across a diverse range of production conditions. In this study, 335 four-day-old watermelon (Citrullus spp.) seedlings were evaluated for total root length, average root diameter, total root surface area, and total root volume. Total root length varied from 8.78 to $181 \mathrm{~cm}(20.6-$ fold variation), total surface area varied from 2 to $35.5 \mathrm{~cm}^{2}$, and average root diameter and total root volume had an 8- and 29.5 -fold variation, respectively. Genotypes PI 195927 (Citrullus colocynthis) and PI 674448 (Citrullus amarus) had the largest total root length values. Accessions PI 674448 and PI 494817 (C. amarus) had the largest total root surface area means. Watermelon cultivars (Citrullus lanatus) had a relatively smaller root system and significantly fewer fibrous roots when compared with the roots of the other Citrullus spp. Positive genetic correlations were identified among total root length, total root surface area, and total root volume. This genetic information will be useful in future breeding efforts to select for multiple root architecture traits in watermelon. Germplasm identified in this study that exhibit superior root traits can be used as parental choices to improve watermelon for root traits.
\end{abstract}

\footnotetext{
Received for publication 17 Apr. 2020. Accepted for publication 1 June 2020 .

Published online 6 July 2020

This research work was supported by grants from the National Watermelon Association (NWA) and USDA National Institute of Food and Agriculture Specialty Crop Research Initiative (2015-51181-24285) awarded to Amnon Levi. We would like to thank Shelby Steck and Laura Massey for their assistance with greenhouse work and root data collection.

A.L. is the corresponding author. E-mail: amnon. levi@usda.gov.

This is an open access article distributed under the CC BY-NC-ND license (https://creativecommons. org/licenses/by-nc-nd/4.0/).
}

Sweet-fleshed (dessert) watermelon (Citrullus lanatus) is a lucrative vegetable crop for growers and is consumed by millions of people around the world (FAOSTAT, http:// www.fao.org/faostat/en/). Cultivated watermelon is related to five other species in the genus Citrullus, including C. amarus (citron), Citrullus mucosospermus (egusi watermelon), C. colocynthis (desert watermelon), Citrullus rehmii, Citrullus ecirrhosus, and Citrullus naudinianus (Chomicki and Renner, 2015; Jarret et al., 1997). C. mucosospermus is native to Western Africa and C. amarus originates from Southern Africa. Several of the related species (including $C$. amarus, C. mucosospermus, C. colocynthis, and $C$. ecirrhosus) can be intercrossed with varying degrees of difficulty with each other and with C. lanatus (Jarret et al., 2017). Citrullus species contain alleles underlying adaptive (fitness) traits that have been inadvertently lost in the cultivated varieties of $C$. lanatus as a result of repeated cycles of breeding, selection, and evolution (Jarret et al., 2017; Levi et al., 2001)

Breeding and improvement of C. lana$t u s$ in the past has historically been primarily focused on improving yield and fruit quality traits. These narrowly focused breeding goals have resulted in a significant genetic bottleneck as evidenced by the limited genetic diversity present in the current commercially grown watermelon varieties (Levi et al., 2001). However, the cultivated sweet watermelon has a wide range of geographical distribution and production, which exposes the crop to challenges related to changing weather patterns and climate (Paris, 2015).

Watermelon crop performance is affected by changing weather conditions. The fruit is composed predominantly of water $(>90 \%)$, therefore water and heat stress can significantly affect fruit yield and quality (Hatfield et al., 2008). Limited soil moisture and elevated temperatures during the growing season can result in inadequate flowering, as well as inability to fend off pests and pathogens, resulting in a marked loss in yield (Krug, 1997; Rubatzky and Yamaguchi, 1997). Given the high moisture content in watermelon, it is vital to identify and develop ideotypes with improved root traits and water-use efficiency.

With the increasing global population and the dwindling availability of arable land, it is critical to develop plant germplasm that can perform optimally under these new crop production constraints (Gilliham et al., 2017). Fluctuating amounts of rainfall and rising temperatures across crop production zones highlight the urgency to develop plant materials that are resilient to these erratic weather patterns (Trenberth et al., 2014).

The root system is the major plant organ involved in water and nutrient acquisition and uptake (Zhu et al., 2011). Root architecture and capacity (number of roots, root volume, length, and surface area) play an important role in water and nutrient acquisition, and in minimizing the negative effects of water and other environmental stresses (Koevoets et al., 2016; Lamaoui et al., 2018). Developing varieties with an improved root system (i.e., that is more robust and efficient) is critical for enhancing plant survival and performance of the watermelon crop during periods of reduced water availability. Identification and quantification of root traits across Citrullus spp. can help identify superior genotypes useful for the improvement of watermelon cultivars.

Water-use efficiency, which refers to the ability of plants to convert absorbed water into economic yield, is an important trait to 
incorporate into watermelon breeding programs and cultivar development pipelines (Fahad et al., 2017). Development of varieties with an improved root system (e.g., longer roots, more root hairs) is critical for enhancing survival and performance of watermelon plants during periods of reduced water availability. Identification of watermelon genotypes with a robust root network that can potentially perform well under changing climate conditions will be useful in maintaining yields that are profitable to commercial growers.

A resilient root architecture could also be important for protection of the watermelon crop from root pathogens, such as Verticillium, Fusarium, and root-knot nematodes (Wimer et al., 2015). Watermelon production can be severely affected by fusarium wilt, whereas genotypes with a branched root system and rich with secondary fibrous roots have an advantage in their ability to minimize or quickly recover from the impact of pathogen damage. Having a robust root system can reduce the damage from soil pathogens, thus allowing the affected plant to grow optimally with minimal reductions in crop yield. Moreover, grafted plants also tend to have an improved performance under both drought and salt stress growth conditions (Yanyan et al., 2018). A survey of root traits across Citrullus spp. can help identify genotypes that are uniquely qualified to better tolerate biotic and abiotic stressors.

The exclusion of methyl bromide fumigants from the market in accordance with the

Table 1. Phenotypic summary statistics for mean, SD, minimum, and maximum, and fold variation values for four root traits for 335 Citrullus germplasm accessions evaluated under greenhouse conditions.

\begin{tabular}{lccrr}
\hline Traits & Mean $( \pm \mathrm{sD})$ & Min. & Max. & Fold variation \\
\hline TRL $(\mathrm{cm})$ & $62.41(27.69)$ & 8.78 & 181.02 & 20.6 \\
TSA $\left(\mathrm{cm}^{2}\right)$ & $10.31(5.03)$ & 2.04 & 35.53 & 17.4 \\
ARD $\left(\mathrm{mm}^{3}\right.$ & $0.54(0.13)$ & 0.27 & 2.15 & 8.0 \\
TRV $\left(\mathrm{cm}^{3}\right)$ & $0.14(0.08)$ & 0.02 & 0.59 & 29.5 \\
\hline
\end{tabular}

\pm SD refers to the standard deviation of the trait means; fold variation refers to the maximum (Max.) relative to the minimum (Min.) values for each trait. $\mathrm{TRL}=$ total root length; $\mathrm{TSA}=$ total root surface $\operatorname{area} ; \mathrm{ARD}=$ average root diameter; TRV $=$ total root volume.
Montreal Protocol on Substances that Deplete the Ozone Layer and the U.S. Clean Air Act (U.S. Environmental Protection Agency, 2012) led to the exploration for new alternatives for the control of soilborne pathogens. One alternative is use of rootstocks resistant to soilborne diseases and nematodes. The use of grafting in watermelon crop production has gained increased popularity over the past decade. The use of disease and pestsusceptible watermelon scions grafted to a resistant rootstock is being used to address the growing burden of soilborne pathogens and the discontinuation of soil fumigants (Davis et al., 2008). Also, it is becoming economically feasible to develop and grow grafted watermelon plants, given the high value of the crops and the potential improvement for increased crop performance in the event of attack from soil pathogens (Keinath and Hassell, 2014; Thies et al., 2010). Successful watermelon grafting requires rootstocks with a robust root system compatible with the selected scions. Previous studies showed that Citrullus amarus accessions have a formidable root system resistant to soilborne diseases and root-knot nematodes, and these accessions are likely candidates as rootstocks for grafted watermelon (Levi

Table 2. List of some of the superior genotypes from the 335 Citrullus spp. accessions evaluated for root morphological traits under greenhouse conditions.

\begin{tabular}{|c|c|c|c|c|c|c|}
\hline \multirow[b]{2}{*}{ Accession } & \multirow[b]{2}{*}{ Species } & \multirow[b]{2}{*}{ Country of origin } & \multicolumn{4}{|c|}{ Root traits } \\
\hline & & & $\overline{\text { TRL }(\mathrm{cm})}$ & TSA $\left(\mathrm{cm}^{2}\right)$ & ARD (mm) & TRV $\left(\mathrm{cm}^{3}\right)$ \\
\hline PI 674448 & CA & Russia & 171.58 & 35.53 & 0.67 & 0.59 \\
\hline PI 494817 & CA & Zambia & 145.59 & 30.19 & 0.66 & 0.50 \\
\hline PI 186490 & $\mathrm{CM}$ & Nigeria & 139.73 & 26.47 & 0.61 & 0.40 \\
\hline PI 482338 & CA & Zimbabwe & 139.38 & 21.56 & 0.47 & 0.27 \\
\hline PI 482326 & CA & Zimbabwe & 126.93 & 24.23 & 0.61 & 0.38 \\
\hline PI 560004 & $\mathrm{CM}$ & Nigeria & 124.60 & 23.69 & 0.61 & 0.36 \\
\hline PI 482299 & CA & Zimbabwe & 124.50 & 24.95 & 0.64 & 0.40 \\
\hline PI 490375 & CL & Mali & 123.16 & 17.28 & 0.45 & 0.20 \\
\hline PI 482303 & $\mathrm{CA}$ & Zimbabwe & 122.91 & 20.42 & 0.53 & 0.28 \\
\hline PI 674448 & $\mathrm{CA}$ & Russia & 122.68 & 23.54 & 0.61 & 0.36 \\
\hline PI 482259 & CA & Zimbabwe & 120.29 & 21.65 & 0.57 & 0.31 \\
\hline PI 500319 & CL & Zambia & 114.72 & 19.48 & 0.55 & 0.27 \\
\hline PI 482315 & $\mathrm{CA}$ & Zimbabwe & 112.30 & 20.67 & 0.59 & 0.31 \\
\hline PI 270564 & CA & South Africa & 111.51 & 15.41 & 0.45 & 0.18 \\
\hline PI 482318 & CA & Zimbabwe & 110.72 & 19.11 & 0.55 & 0.27 \\
\hline PI 482286 & $\mathrm{CA}$ & Zimbabwe & 108.82 & 21.09 & 0.62 & 0.33 \\
\hline PI 482309 & CA & Zimbabwe & 106.34 & 18.32 & 0.55 & 0.25 \\
\hline PI 482261 & $\mathrm{CA}$ & Zimbabwe & 103.32 & 12.53 & 0.39 & 0.12 \\
\hline PI 212094 & CL & Afghanistan & 100.97 & 13.51 & 0.51 & 0.15 \\
\hline PI 635631 & $\mathrm{CL}$ & United States & 100.81 & 17.01 & 0.54 & 0.23 \\
\hline PI 379231 & $\mathrm{CL}$ & Macedonia & 21.07 & 4.78 & 0.73 & 0.09 \\
\hline PI 211851 & $\mathrm{CL}$ & Iran & 19.53 & 2.75 & 0.45 & 0.03 \\
\hline PI 635614 & CL & United States & 18.25 & 2.99 & 0.59 & 0.04 \\
\hline PI 635713 & CL & United States & 16.05 & 3.81 & 0.82 & 0.08 \\
\hline
\end{tabular}

$\mathrm{TRL}=$ total root length $\mathrm{TSA}=$ total root surface area $\mathrm{ARD}=$ average root diameter; $\mathrm{TRV}=$ total root volume; $\mathrm{CC}=$ Citrullus colocynthis $; \mathrm{CA}=$ Citrullus amarus; $\mathrm{CM}=$ Citrullus mucosospermus; $\mathrm{CL}=$ Citrullus lunatus; $\mathrm{LSD}=$ least significant difference. 
et al., 2013; Thies and Levi, 2007; Thies et al., 2010; Wechter et al., 2012).

Evaluation of root traits across Citrullus spp. is a means to identify superior genotypes useful for the improvement and development of modern watermelon cultivars. Hence, the primary objective of this study was to determine the phenotypic diversity present in the U.S. Department of Agriculture (USDA) Citrullus spp. germplasm collection for root traits likely to contribute to enhanced water and nutrient uptake and identify superior genotypes that can be deployed to improve the watermelon crop's ability to remain productive during periods of water shortage and environmental stress. In addition, we sought to determine the genetic relationship among these various root traits across the Citrullus spp. germplasm.

\section{Materials and Methods}

Plant material and experimental design. A total of 335 Citrullus spp. accessions were evaluated for root traits in this study. The seeds of all accessions were originally obtained from the USDA genebank in Griffin, GA. Individual plants were then selfpollinated for one generation to reduce heterozygosity, which is common in crosspollinating plant species. The study included 105 C. amarus, 14 C. colocynthis, $184 C$. lanatus, and 32 C. mucosospermus genebank accessions. Most of the genotypes (185) were collected/received from Africa. There were 71 genotypes from Asia, 29 from Europe, and 43 from North America, with the remainder from Central America, South America, and Oceania (Supplemental Table 1). The experiments were performed in the greenhouse as a completely randomized design with four replications.

Plant growth conditions and phenotyping of the root traits. Seeds were sown individually into an $8-\mathrm{cm}$ square pots filled with a mixture of $90 \%$ Sungro metro mix and $10 \%$ sand (Agawam, MA) and watered as needed to ensure optimal crop growth in the greenhouse. Seedlings were harvested to assay for root traits following germination, on opening of the cotyledon leaves but before the emergence of the first true leaf. In watermelon production, rootstocks are ready for grafting at 7 to $10 \mathrm{~d}$ after seed sowing, hence why we used the cotyledon (before emergence of the first true leaf) developmental stage as the time point for root sample collection (Hassell et al., 2008; Mohamed et al., 2014). Samples were harvested in the greenhouse by gently removing them from the pots to minimize root breakage/loss and then gently soaked in water and cleaned to remove any soil from the root surface.

Once harvested and cleaned, the root samples were placed in Ziploc bags with a moist paper towel and kept in a refrigerator $\left(4{ }^{\circ} \mathrm{C}\right)$ for subsequent analysis. The moist towel was used to prevent samples from drying out during the short-term storage. Samples were kept at $4{ }^{\circ} \mathrm{C}$ for no longer than $3 \mathrm{~d}$ before being evaluated for the root traits.
The roots for each genotype were removed from the Ziploc bags and floated in $\approx 1 \mathrm{~cm}$ of water in a $20 \times 25-\mathrm{cm}$ transparent plexiglass tray during image scans. Submersion (floatation) of the roots in water promoted root separation and thus facilitated the accurate scanning of the roots. While in the tray, the roots were scanned on a desk Epson Perfection V800 Photo scanner (Epson America Inc., Long Beach, CA) calibrated with grayscale scanning and 600-dpi resolution (Costa, et al., 2001). The root morphology traits measured included total root length (TRL), total root surface area (TSA), total root volume (TRV), and average root diameter (ARD). The root phenotypes were quantified via analysis of the scanned images using an established WinRHIZO Pro 2015a Regent instrument software (Regent Instruments Inc., Quebec, Ontario, Canada) previously described by Arsenault et al. (1995). The WinRHIZO software also generated values of TRL, TSA, and TRV for each of the root diameter size categories $(0-0.5,0.5-1.0,1.0$ $1.5,1.5-2.0,2.0-2.5$, and $>2.5 \mathrm{~mm})$. Most studies delineate fine/secondary roots and root hairs as those with root diameters less than $0.5 \mathrm{~mm}$ (Liu et al., 2018; Polania et al., 2017).

Statistical data analysis. The phenotypic data were analyzed using PROC MIXED in SAS version 9.4 (SAS Institute, 2013) following the statistical model: $Y_{i j}=\mu+G_{i}+R_{j}+$ $\varepsilon_{\mathrm{ij}}$. In this statistical model, $\mathrm{Y}_{\mathrm{ij}}$ is the measured phenotypic value such as TRL for the $i^{\text {th }}$ genotype in the $j^{\text {th }}$ replication; $\mu$ is the grand mean; $\mathrm{G}_{\mathrm{i}}$ is the fixed variable effect of the $i^{\text {th }}$ genotype; $R_{j}$ is the random variable effect of the $j^{\text {th }}$ replication; and $\varepsilon_{\mathrm{ij}}$ is the residual error term assumed to be normally distributed with mean $=0$. To compare differences among genotypes, mean separation was performed using Fisher's protected least significant difference in SAS version 9.4 (SAS Institute, 2013). Genotypic correlations among the root traits were computed using multivariate restricted maximum likelihood estimation with SAS PROC MIXED as described in Holland (2006). To visually assess trait distribution/ variability patterns within the traits data, hist() and boxplot() functions were used to create histograms and boxplots respectively
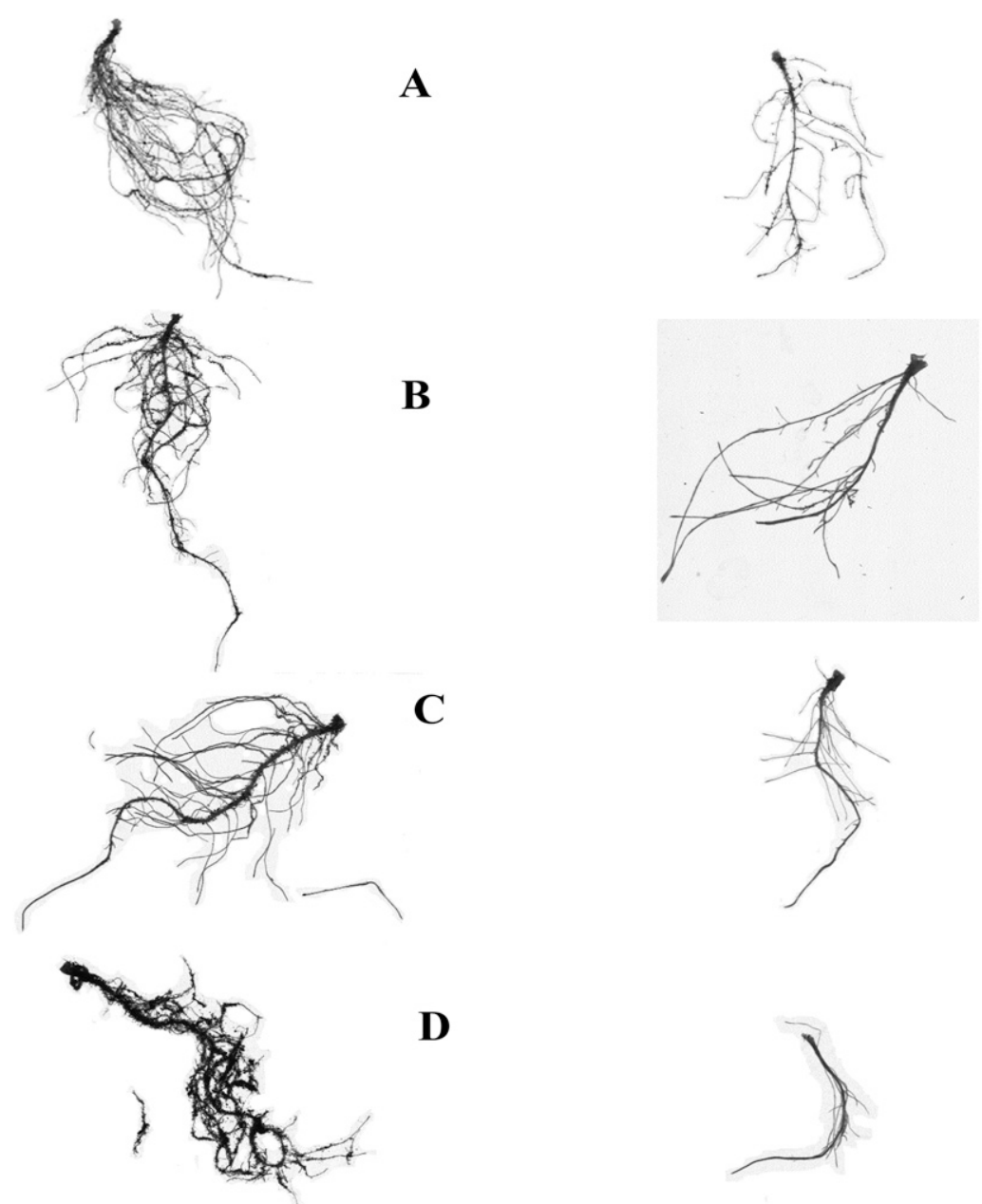

E
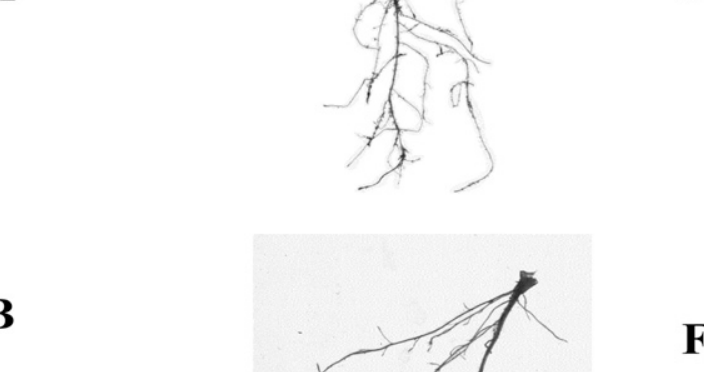

Fig. 1. Images displaying variability in root traits of six Citrullus accessions with genotypes A-D exhibiting superior root trait performance, whereas $\mathbf{E}-\mathbf{H}$ had low root trait means for total root length and total root surface area. A is PI 195927; $\mathbf{B}$ is PI 674448; $\mathbf{C}$ is PI 494528; $\mathbf{D}$ is 494817; $\mathbf{E}$ is PI 296341 F is PI 296337; G is PI 635654; and $\mathbf{H}$ is Allsweet. Genotypes $\mathbf{A}$ and $\mathbf{C}$ are Citrullus colocynthis and Citrullus mucosospermus, respectively; genotypes $\mathbf{B}, \mathbf{D}, \mathbf{E}$, and $\mathbf{F}$ are Citrullus amarus; $\mathbf{G}$ and $\mathbf{H}$ are Citrullus lanatus. 
in the $\mathrm{R}$ programming language ( $\mathrm{R}$ Core Team, 2018).

\section{Results}

Genotype effects and descriptive summary statistics. The analysis of variance in SAS showed that there was a significant effect of genotype on all of the evaluated root traits $(P=0.0001)$. TRL ranged 8.78 to $181.02 \mathrm{~cm}$ with a 20.6-fold variation. TSA varied from 2.04 to $35.53 \mathrm{~cm}^{2}$ with a 17.4 -fold change.
ARD ranged from 0.27 to $2.15 \mathrm{~mm}$ with an 8 -fold variation, and TRV ranged from 0.02 to $0.59 \mathrm{~cm}^{3}$ with a fold change of 29.5 (Table 1).

Genotypes PI 195927 (C. colocynthis) collected in Ethiopia, PI 674448 (C. amarus) collected in Russia, and PIs 494528 and 306782 (both C. mucosospermus collected in Nigeria) had the highest TRL values (Table 2; Fig. 1). Genotypes PI 674448 and PI 494817 both C. amarus collected in Russia and Zambia, respectively, had the largest
TSA values (Table 2; Supplemental Table 1; Fig. 1)

Most of the accessions with the greatest TRL and TSA values belonged to C. amarus (citron) and C. mucosospermus (egusi) watermelon types (Table 2; Supplemental Table 1). Most of the genotypes with the smallest TRL values belonged to C. lanatus, many of which are heirloom cultivars developed in the United States (Supplemental Table 1). Citrullus lanatus genotypes PI 269677 and PI 277977 collected in Belize
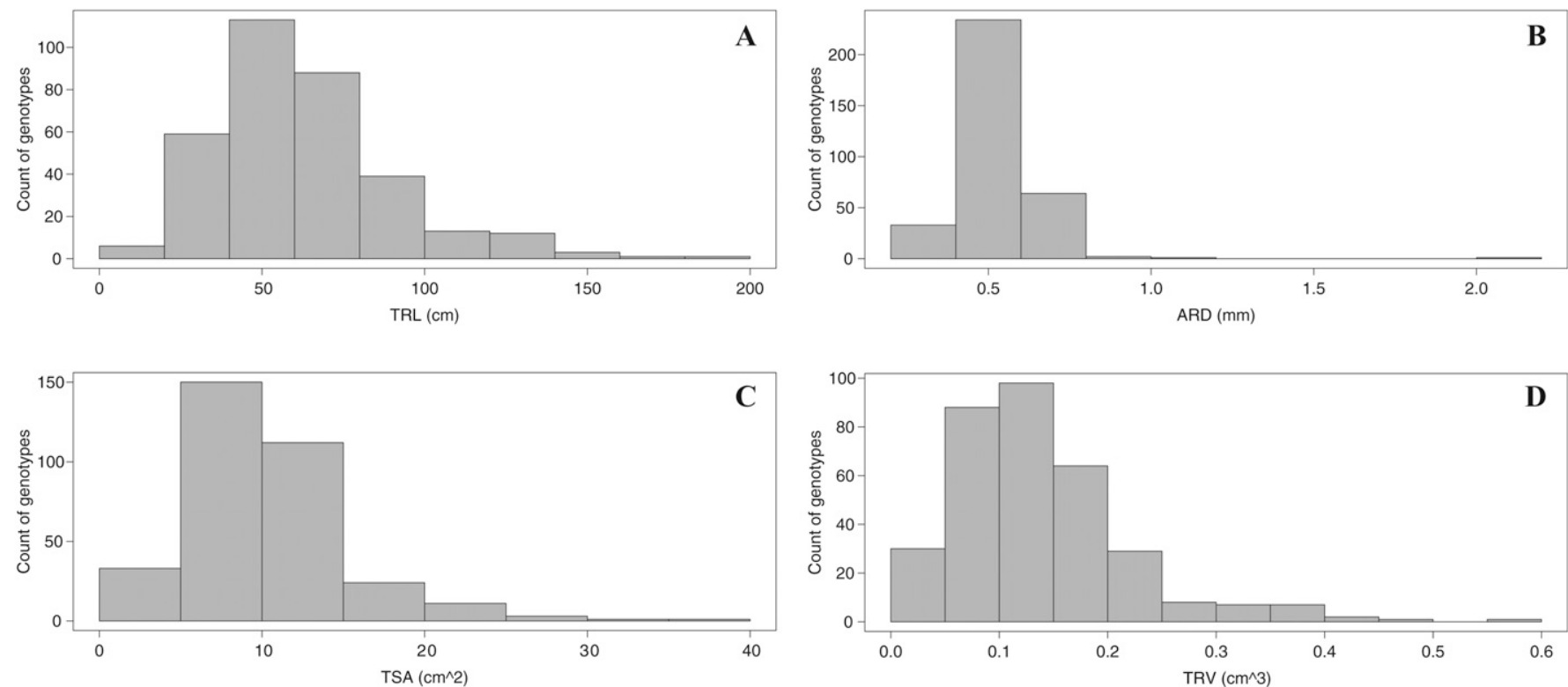

Fig. 2. Histograms showing the distributions of four root morphological traits [(A) total root length (TRL), (B) average root diameter (ARD), (C) total root surface area (TSA), and (D) total root volume (TRV)] across 335 Citrullus spp. genebank accessions.
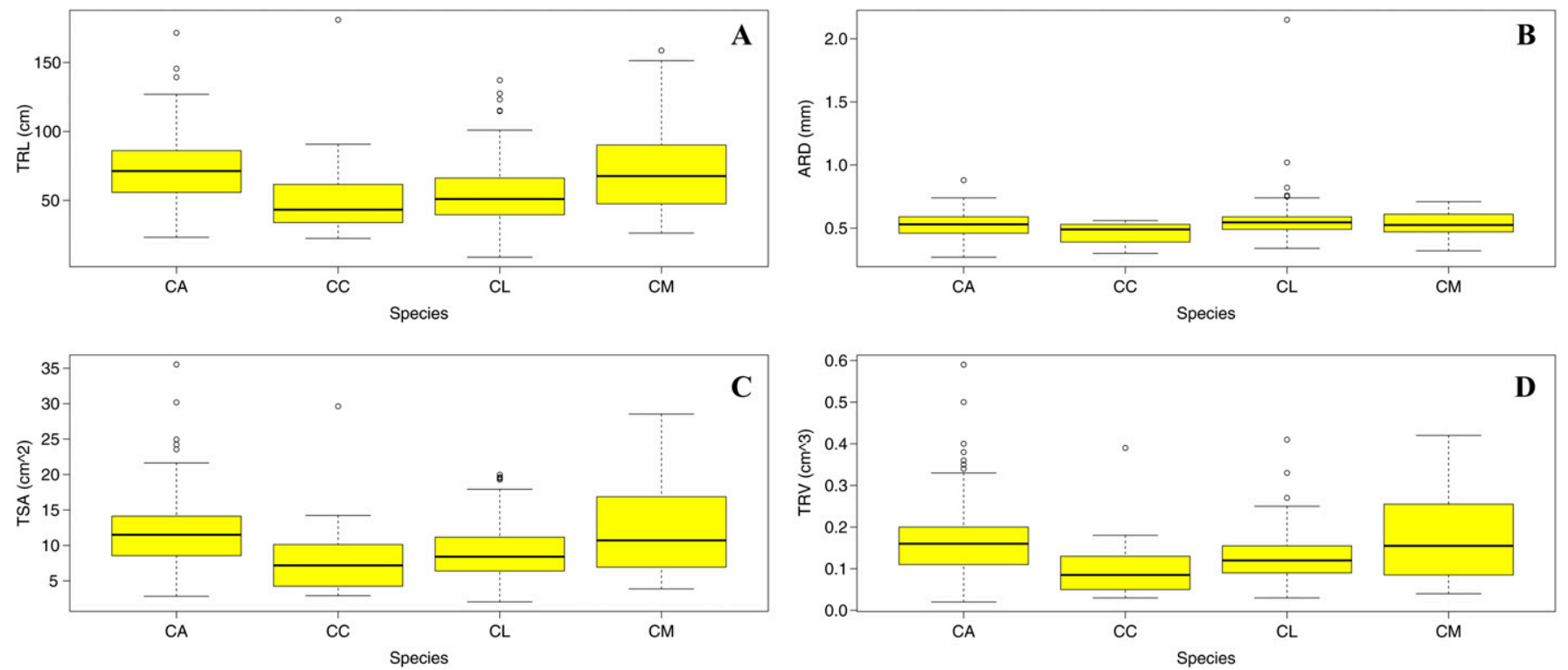

Fig. 3. Boxplot showing the variability of four root morphological traits [(A) total root length (TRL), (B) average root diameter (ARD), (C) total root surface area (TSA), and (D) total root volume (TRV)] across four species of Citrullus as evaluated under greenhouse conditions. CA $=$ Citrullus amarus; $\mathrm{CC}=$ Citrullus colocynthis; $\mathrm{CL}=$ Citrullus lanatus; $\mathrm{CM}=$ Citrullus mucosospermus. 
and Turkey, respectively, had the largest ARD values. Genotypes belonging to $C$. amarus and C. mucosospermus had the smallest ARD (Supplemental Table 1).

Genotypes PI 674448 and PI 494817 collected from Russia and Zambia, respectively, were both C. amarus and had the largest TRV values (Supplemental Table 1). Most of the C. lanatus genotypes, including PI 379231 (Mrezasto Zelana from Macedonia), PI 635614 (U.S. cv Klondike Striped Blue Ribbon), PI 635713 (Calhoun Gray), PI 635598 (Golden Midget), and Allsweet had smaller TRV values (Table 2; Supplemental Table 1).The histograms for the root traits exhibited continuous distributions (Fig. 2). Variability for TRL, TSA, and TRV was largest within the C.amarus, C. colocynthis, and $C$. mucosospermus accessions, whereas variability in ARD values was largest across the C. lanatus accessions (Fig. 3).

Genotypes PI 195927 (C. colocynthis) and PI 306782 (C. mucosospermus) from Ethiopia and Nigeria, respectively, had larger TRL values within the 0 - to 0.5 -mm-diameter size categories, implying presence of more fine roots and root hairs for these accessions (Table 3). It is worth noting that most of the cultivated sweet watermelon (C. lanatus) genotypes had lower TRL values within the 0.1- to 0.5-mm-diameter size class (Table 3; Supplemental Table 2).

These cultivated type genotypes with small TRL scores were from Turkey, Mace- donia, and the United States. TRL exhibited more variability within the $0-$ to $0.5-\mathrm{mm}$ diameter size category compared with the other diameter size classes across the 335 Citrullus spp. accessions (Fig. 4). Wide variability for TSA was observed within the 0 - to 0.5 - and 0.5 - to $1.0-\mathrm{mm}$ root diameter classes, whereas TRV was most variable within the 0.5 - to $1.0-, 1.0$ - to $1.5-, 1.5$ - to $2.0-$, and 2.0to 2.5 -mm-diameter sizes (Fig. 4).

Trait correlations. Genotypic correlations among root traits ranged from -0.08 to 0.97 (Table 4). TRL was positively correlated with TSA $(\mathrm{r}=0.95 ; P<0.0001)$ and TRV $(\mathrm{r}=$ $0.85 ; P<0.0001)$ but negatively correlated with ARD $(\mathrm{r}=-0.08 ; P=0.4186)$. TSA was positively correlated with both ARD ( $\mathrm{r}=$ $0.20 ; P=0.0380)$ and TRV $(\mathrm{r}=0.97 ; P<$ $0.0001)$. ARD was also positively correlated with TRV $(\mathrm{r}=0.39 ; P=0.0005)$ (Table 4$)$. Overall, pairwise genetic correlation between TRL and TSA or TRV showed strong positive correlations $(r \geq 0.79$ ), whereas the pairwise correlations between ARD and TSA or ARD with TRV showed low positive correlations ( $\mathrm{r} \leq 0.44)$, as shown in Table 4 .

\section{Discussion}

Variability in root traits is critical in efforts to genetically improve crop performance and adaptation to varying production conditions, including water-limiting stress via modifications to plant root architecture
(Lynch, 2007). Development of crops with robust root phenotypes/architecture is a current goal for numerous crop breeding programs (Comas et al., 2013). Characterization of the native diversity in root traits within and among Citrullus species provides a foundation for selection of parental lines that can be used in breeding watermelon for enhanced nutrient and water acquisition, as well as identification of genotypes that might be well suited for use as rootstocks.

Many of the cultivated watermelon $(C$. lanatus) cultivars evaluated in this study had a relatively small root system when compared with accessions of C. mucosospermus or C. amarus (Table 2; Figs. 1 and 3; Supplemental Table 1). This is likely due to a selection sweep resulting from many years of breeding watermelon for desirable fruit qualities, as well as the transition from the cultivation of watermelon genotypes originating from the arid regions in Northern Africa where there are limited water resources to more tropical or humid regions of the world with more abundant water resources and/or irrigation (Jensen et al., 2011; Paris, 2015).

The data reported here indicate that there is a wide variation in overall root system size (TRL and TSA) among accessions of $C$. colocynthis (Fig. 3). This might be expected based on the documented genetic diversity that is known to exist among $C$. colocynthis accessions collected in the desert regions of Northern Africa, the Middle East, and Asia

Table 3. List of some of the superior genotypes from the 335 Citrullus spp. accessions for root morphological traits within the 0 - to 0.5 -mm root diameter size class (secondary roots) evaluated under greenhouse conditions.

\begin{tabular}{|c|c|c|c|c|c|}
\hline \multirow[b]{2}{*}{ Accession } & \multirow[b]{2}{*}{ Species } & \multirow[b]{2}{*}{ Country of origin } & \multicolumn{3}{|c|}{ Root traits } \\
\hline & & & TRL $(\mathrm{cm})$ & $\operatorname{TSA}\left(\mathrm{cm}^{2}\right)$ & $\operatorname{TRV}\left(\mathrm{cm}^{3}\right)$ \\
\hline PI 195927 & $\mathrm{CC}$ & Ethiopia & 127.30 & 8.95 & 0.07 \\
\hline PI 306782 & $\mathrm{CM}$ & Nigeria & 108.43 & 7.70 & 0.06 \\
\hline PI 635691 & $\mathrm{CL}$ & United States & 104.34 & 7.21 & 0.05 \\
\hline PI 482338 & $\mathrm{CA}$ & Zimbabwe & 101.21 & 7.81 & 0.06 \\
\hline PI 494528 & $\mathrm{CM}$ & Nigeria & 100.85 & 8.90 & 0.08 \\
\hline PI 674448 & $\mathrm{CA}$ & Russia & 99.73 & 7.70 & 0.07 \\
\hline PI 494817 & $\mathrm{CA}$ & Zambia & 94.43 & 6.37 & 0.05 \\
\hline PI 490375 & $\mathrm{CL}$ & Mali & 93.40 & 7.35 & 0.06 \\
\hline PI 482302 & $\mathrm{CA}$ & Zimbabwe & 93.18 & 7.16 & 0.05 \\
\hline PI 254744 & $\mathrm{CL}$ & Senegal & 93.10 & 6.99 & 0.06 \\
\hline PI 482303 & $\mathrm{CA}$ & Zimbabwe & 89.58 & 7.24 & 0.06 \\
\hline PI 482246 & $\mathrm{CA}$ & Zimbabwe & 88.67 & 6.27 & 0.05 \\
\hline PI 186490 & $\mathrm{CM}$ & Nigeria & 86.61 & 6.44 & 0.05 \\
\hline PI 482261 & $\mathrm{CA}$ & Zimbabwe & 85.40 & 7.01 & 0.06 \\
\hline PI 512398 & $\mathrm{CL}$ & Spain & 85.39 & 7.36 & 0.07 \\
\hline PI 270564 & $\mathrm{CA}$ & South Africa & 85.29 & 7.28 & 0.06 \\
\hline PI 494531 & $\mathrm{CM}$ & Nigeria & 83.37 & 6.92 & 0.06 \\
\hline PI 482326 & $\mathrm{CA}$ & Zimbabwe & 82.11 & 5.79 & 0.05 \\
\hline PI 500319 & $\mathrm{CL}$ & Zambia & 81.38 & 7.07 & 0.06 \\
\hline PI 212094 & CL & Afghanistan & 81.32 & 6.66 & 0.05 \\
\hline PI 255136 & $\mathrm{CA}$ & South Africa & 80.69 & 5.76 & 0.04 \\
\hline PI 560004 & $\mathrm{CM}$ & Nigeria & 80.49 & 8.14 & 0.07 \\
\hline PI 601308 & $\mathrm{CL}$ & United States & 15.88 & 1.01 & 0.01 \\
\hline PI 211851 & $\mathrm{CL}$ & Iran & 15.32 & 1.30 & 0.01 \\
\hline PI 276445 & $\mathrm{CL}$ & Jordan & 15.19 & 1.39 & 0.01 \\
\hline PI 635614 & CL & United States & 12.29 & 0.96 & 0.01 \\
\hline Allsweet & $\mathrm{CL}$ & United States & 10.16 & 0.83 & 0.01 \\
\hline PI 379231 & $\mathrm{CL}$ & Macedonia & 9.36 & 0.98 & 0.01 \\
\hline PI 635713 & CL & United States & 8.00 & 0.65 & 0.01 \\
\hline PI 635596 & CL & United States & 6.16 & 0.54 & 0.01 \\
\hline PI 277977 & CL & Turkey & 4.57 & 0.42 & 0.01 \\
\hline $\operatorname{LSD}(\alpha=0.05)$ & & & 19.65 & 1.61 & 0.01 \\
\hline
\end{tabular}



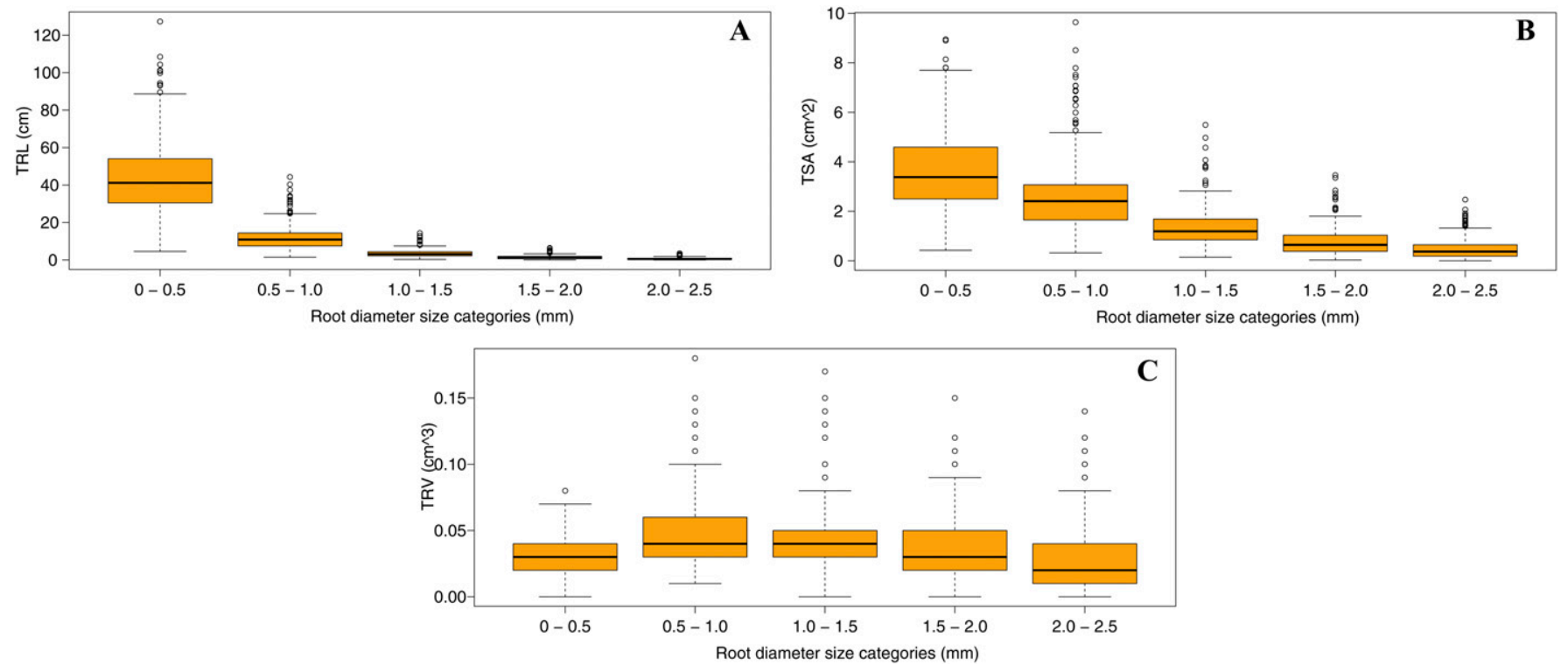

Fig. 4. Boxplot showing the variability of three root traits [(A) total root length (TRL), (B) total root surface area (TSA), and (C) total root volume (TRV)] within five root diameter classes across the 335 Citrullus genebank accessions evaluated under greenhouse conditions.

(Levi et al., 2017). Desert plants often have a more elaborate root architecture with longer roots that penetrate deeply into the soil, thus offering larger water and nutrient absorptive surface areas (Sandquist, 2014). In the present study, the African C. colocynthis accession (PI 195927) sourced from Ethiopia had a superior average TRL $(181.02 \mathrm{~cm})$ and TSA of $29.63 \mathrm{~cm}^{2}$ (Table 2). However, it is worth noting that several $C$. colocynthis genotypes exhibited a relatively small root system. Also, in our greenhouse experiments, seeds of $C$. colocynthis accessions were slower to germinate when compared with those of other Citrullus species. Many desert plants produce seeds that rapidly germinate on the onset of a rainy season, but may also tend to produce seeds with delayed germination as a survival mechanism by remaining dormant until the water supply is sufficient for seedling survival (Gutterman, 1972).

Root architecture traits like root length, root area, and abundance of secondary roots are often important traits for the plants' response to water stress (drought) and soilborne pathogens (Comas et al., 2013; Thies and Levi, 2007; Wechter et al., 2012). Survey of past literature revealed that some of the accessions from our study with superior TRL, TSA, and proportion of secondary roots (PI 482303, PI 482246, PI 482309, and PI 482302) have also been previously reported to have strong tolerance to seedling wilt induced by water stress (Zhang et al., 2011). Genotypes PI 482246, PI 255136, and PI 270564 with superior root traits performance from this research have also previously exhibited $33 \%$ to $56 \%$ survival when challenged with Fusarium oxysporum f. sp. niveum race 2 under greenhouse growth conditions (Wechter et al., 2012). The accessions of PI 482338, PI 482303, and PI 482259 had superior root traits performance and have also been reported to show reduced root galling and nematode egg production when infected by root-knot nematodes (Thies and Levi, 2007). Genotypes with significant overlap for superior root traits and resistance to water stress and soilborne pathogens based on the present research and the preceding historical studies will be important parental candidates for gene pyramiding of alleles controlling tolerance to both biotic and abiotic stresses in watermelon crop improvement and production.

The continuous distribution of the root traits depicted by the histograms (Fig. 2) suggests presence of quantitative inheritance of the examined root traits and the involvement of multiple loci underlying these traits. Previous studies have reported numerous genetic loci controlling root length and surface area in maize, wheat, and common bean (Bhatta et al., 2019; Ju et al., 2018; Lin et al., 2019; Polania et al., 2017; Wang et al., 2019). The trait distribution patterns generated in this study will serve as a benchmark in future genetic studies seeking to characterize the genetic basis and inheritance of root phenotypes in watermelon.

The $C$. amarus (citron) accessions exhibited the greatest variability for TRL, TSA, and TRV. C. amarus has been classified as a sister species to the cultivated sweet watermelon (C. lanatus) (Chomicki and Renner, 2015; Jarret et al., 1997; Levi et al., 2013). In addition, a large number of $C$. amarus genotypes have been reported to be resistant/tolerant to root-knot nematodes, fusarium wilt races 1 and 2, and also found to be robust rootstocks for the production of grafted watermelon (Thies and Levi, 2007; Thies et al., 2010; Wechter et al., 2012). C. amarus and $C$. lanatus can be readily intercrossed and produce viable hybrids (Levi et al., 2001). Thus, it is feasible to move the
Table 4. Genotypic correlations among the evaluated root traits of the 335 Citrullus germplasm accessions grown under greenhouse conditions.

\begin{tabular}{lcccc}
\hline Traits & TRL & TSA & ARD & TRV \\
\hline TRL & - & $0.95^{* *}$ & $-0.08 \mathrm{NS}$ & $0.85^{* *}$ \\
TSA & & - & $0.20^{*}$ & $0.97^{* *}$ \\
ARD & & & - & $0.39^{* *}$ \\
TRV & & & & -
\end{tabular}

TRL $=$ total root length; TSA $=$ total root surface area; $\mathrm{ARD}=$ average root diameter; TRV $=$ total root volume.

NS, *, **Nonsignificant or significant at $P \leq 0.05$ or 0.001 , respectively.

root architecture trait alleles present in $C$. amarus into the cultivated (sweet-fleshed) watermelon genetic background.

The presence of fine (secondary) roots and root hairs is important for nutrient and water uptake in plants as a result of the increased absorptive surfaces that they provide. An abundance of secondary roots can result in better crop performance and resilience when under attack from soilborne pathogens, especially Fusarium and root-knot nematode (Thies et al., 2010). Previous studies have indicated that root exudates from secondary roots into the rhizosphere play an important role nutrient acquisition, combating invasive weed species through allelopathy and attraction of beneficial microbes within the root zone that inhibit soilborne pathogens like Fusarium and nematodes (Chen et al., 2014; Kerry, 2000; Korenblum et al., 2020; Walker et al., 2003). Fine roots can more easily intercalate into the adjacent soil/root zone allowing the plants to more effectively and efficiently absorb water and nutrients that promote and sustain growth. Fine roots provide a relatively larger surface area for water and nutrient uptake and have a lower carbon 
and energy requirement for their function (Lynch, 2011). The Citrullus genotypes with a large mass of secondary roots identified in the present study can be used as breeding stocks to increase the number of fine roots present in cultivated watermelon.

Trait correlation analysis is often used to determine positive and negative associations among phenotypes, identify parental combinations useful in cultivar development, and in minimizing trait measurement redundancy (Yan and Fregeau-Reid, 2008). The occurrence of positive correlations among traits suggests that simultaneous selection and improvement of such phenotypes through plant breeding is feasible. The present study findings are in agreement with those of Wasson and coworkers who also reported positive correlations among TRL, TSA, and TRV in wheat (Wasson et al., 2012). This suggests that these phenotypes can be targeted concurrently for watermelon improvement for root architecture traits.

\section{Conclusion}

This is the first report on an evaluation of root traits in a collection of Citrullus spp. germplasm. The results in this study indicate the presence of great variability in root traits within and among the Citrullus spp. accessions. Lower mean values of root traits were observed within the $C$. lanatus genotypes, including cultivars developed in the United States. A high percentage of cultivated watermelon genotypes had a small root system and were generally lacking secondary fibrous roots when compared with $C$. lanatus landraces or accessions of other Citrullus spp. This significant reduction in fibrous roots is likely to be a result of many years of cultivation and selection for watermelon ideotypes having desirable fruit quality traits and adaptation to geographical regions with moist soil conditions different from those in the arid areas present at the centers of origin of Citrullus spp. in Southern and Northern Africa. The identification of Citrullus genotypes with extensive root systems and trait associations will be useful in future genetic studies of root traits and in breeding programs seeking to improve the root system architecture of watermelon.

\section{Literature Cited}

Arsenault, J.L., S. Poulcur, C. Messier, and R. Guay. 1995. WinRHIZO ${ }^{\text {TM }}$, a root-measuring system with a unique overlap correction method. HortScience 30:906 (abstr.).

Bhatta, M., V. Shamanin, S. Shepelev, P.S. Baenzinger, V. Pozherukova, I. Pototskaya, and A. Morgounov. 2019. Marker-trait associations for enhancing agronomic performance, disease resistance, and grain quality in synthetic and bread wheat accessions in western Siberia. G3 9:4209-4222.

Chen, Y.C., B.N. Kidd, L.C. Carvalhais, and P.M. Schenk. 2014. Molecular defense responses in roots and the rhizosphere against Fusarium oxysporum. Plant Signal. Behav. 9:e977710.

Chomicki, G. and S.S. Renner. 2015. Watermelon origin solved with molecular phylogenetics including Linnaean material: Another example of museomics. New Phytol. 205:526-532.

Comas, L.H., S.R. Becker, V.M. Cruz, P.F. Byrne, and D.A. Dierig. 2013. Root traits contributing to plant productivity under drought. Front. Plant Sci. 4:1-16.

Costa, C., L.M. Dwyer, C. Hamel, D.F. Muamba, X.L. Wang, L. Nantais, and D.L. Smith. 2001. Root contrast enhancement for measurement with optical scanner-based image analysis. Can. J. Bot. 79:23-29.

Davis, A.R., P. Perkins-Veazie, R.L. Hassell, A Levi, S.R. King, and X. Zhang. 2008. Grafting effects on vegetable quality. HortScience 43:1670-1672.

Fahad, S., A.A. Bajwa, U. Nazir, S.A. Anjum, A. Farooq, A. Zohaib, S. Sadia, W. Nasim, S. Adkins, S. Saud, M.Z. Ihsan, H. Alharby, C. Wu, D. Wang, and J. Huang. 2017. Crop production under drought and heat stress: Plant responses and management options. Front. Plant Sci. 8:1-16.

Gilliham, M., J.A. Able, and S.J. Roy. 2017. Translating knowledge about abiotic stress tolerance to breeding programs. Plant J. 90:898-917.

Gutterman, Y. 1972. Delayed seed dispersal and rapid germination as survival mechanisms of the desert plant Blepharis persica (Burm.) kuntze. Oecologia 10:145-149.

Hassell, R.L., F. Memmott, and D.G. Liere. 2008. Grafting methods for watermelon production. HortScience 43:1677-1679.

Hatfield, J.L., K.J. Boote, B.A. Kimball, D.W Wolfe, D.R. Ort, R.C. Izaurralde, A.M. Thompson, J.A. Morgan, H.W. Polley, P.A. Fay, T.L. Mader, and G.L. Hahn. 2008. The effects of climate change on agriculture, land resources, water resources, and biodiversity. Report by the U.S. climate change science program and the subcommittee on global change research. U.S Department of Agriculture, Washington, DC. p. 21-74.

Holland, J.B. 2006. Estimating genotypic correlations and their standard errors using multivariate restricted maximum likelihood estimation with SAS PROC MIXED. Crop Sci. 46:642654.

Jarret, R.L., G.R. Bauchan, W.W. Oswald, K. Arumuganathan, and J.P. Shields. 2017. Notes on Citrullus spp.: Pollen morphology, C values, and interspecific hybridization. Crop Sci. 57:856-864.

Jarret, R.L., L.C. Merrick, T. Holms, J. Evans, and M.K. Aradhya. 1997. Simple sequence repeats in watermelon (Citrullus lanatus (Thunb.) Matsum. and Nakai). Genome 40:433-441.

Jensen, B.D., M.A. Hamattal, F.A. Toure, and A.D. Nantoume. 2011. Watermelons in the sand of Sahara: Cultivation and use of indigenous landraces in the Tombouctou Region of Mali. Ethnobotany research and applications. $14 \mathrm{Feb}$. 2020. <www.ethnobotanyjournal.org/vol9/i15473465-09-151>.

Ju, C., W. Zhang, Y. Liu, Y. Gao, X. Wang, J. Yan, X. Yang, and J. Li. 2018. Genetic analysis of seedling traits reveals the association of root trait with other agronomic traits in maize. BMC Plant Biol. 18:1-15.

Keinath, A.P. and R.L. Hassell. 2014. Suppression of Fusarium wilt caused by Fusarium oxysporum f. sp. niveum race 2 on grafted triploid watermelon. Plant Dis. 98:1326-1332.

Kerry, B.R. 2000. Rhizosphere interactions and the exploitation of microbial agents for the biological control of plant parasitic nematodes. Annu. Rev. Phytopathol. 38:423-441.

Koevoets, I.T., J.H. Venema, J.T. Elzenga, and C. Testerink. 2016. Roots withstanding their en- vironment: Exploiting root system architecture responses to abiotic stress to improve crop tolerance. Front. Plant Sci. 7:1-19.

Korenblum, E., Y. Dong, J. Szymanski, S. Panda, A. Jozwiak, H. Massalha, S. Meir, I. Rogachev, and A. Aharoni. 2020. Rhizosphere microbiome mediates systemic root metabolite exudation by root-to-root signaling. Proc. Natl. Acad. Sci. USA 117:3874-3883.

Krug, H. 1997. Environmental influences on development, growth, and yield, p. 101-180. In: H.C. Wien (ed.). The physiology of vegetable crops. CAB International, Wallingford, UK.

Lamaoui, M., M. Jemo, R. Datla, and F. Bekkaoui. 2018. Heat and drought stresses in crops and approaches to their mitigation. Front Chem. 19:1-14.

Levi, A., A.M. Simmons, L. Massey, J. Coffey, W.P. Wechter, R.L. Jarret, Y. Tadmor, P. Nimmakayala, and U.K. Reddy. 2017. Genetic diversity in the desert watermelon Citrullus colocynthis and its relationship with Citrullus species as determined by high frequency oligonucleotides-targeting active gene markers. J. Amer. Soc. Hort. Sci. 142:47-56.

Levi, A., C.E. Thomas, T.C. Wehner, and X. Zhang. 2001. Low genetic diversity indicates the need to broaden the base of cultivated watermelon. HortScience 36:1096-1101.

Levi, A., J.A. Thies, W.P. Wechter, H.F. Harroson, A.M. Simmons, U.K. Reddy, P. Nimmakayala, and Z. Fei. 2013. High frequency oligonucleotides targeting active gene (HFO-TAG) markers reveal wide genetic diversity among Citrullus spp. accessions useful for enhancing disease or pest resistance in watermelon cultivars. Genet. Resources Crop Evol. 60:427-440.

Lin, Y., X. Yi, S. Tang, W. Chen, F. Wu, X. Yang, X. Jiang, H. Shi, J. Ma, G. Chen, G. Chen, Y. Zheng, Y. Wei, and Y. Liu. 2019. Dissection of phenotypic and genetic variation of droughtrelated traits in diverse Chinese wheat landraces. Plant Gene 12:1-14.

Liu, Y., G. Wang, K. Yu, P. Li, L. Xiao, and G. Liu. 2018. A new method to optimize root order classification based on the dimeter interval of fine roots. Sci. Rep. 82:2960.

Lynch, J.P. 2007. Roots of the second green revolution. Aust. J. Bot. 55:493-512.

Lynch, J.P. 2011. Root phenes for enhanced soil exploration and phosphorus acquisition: Tools for the future crops. Plant Physiol. 156:1041-1049.

Mohamed, F.H., K.E. Abd El-Hamed, M.W.M. Elwan, and M.N.E. Hussien. 2014. Evaluation of different grafting methods and rootstocks in watermelon grown in Egypt. Scientia Hort. 168:145-150.

Paris, H.S. 2015. Origin and emergence of the sweet dessert watermelon, Citrullus lanatus. Ann. Bot. 116:133-148.

Polania, J., C. Poschenrieder, I. Rao, and S. Beebe. 2017. Root traits and their potential links to plant ideotypes to improve drought resistance in common bean. Theor. Exp. Plant Physiol. 29:143-154.

R Core Team. 2018. R: A language and environment for statistical computing. R foundation for statistical computing, Vienna, Austria. 13 Dec. 2019. <https://www.R-project.org/>.

Rubatzky, V.E. and M. Yamaguchi. 1997. Environmental factors influencing the growth of vegetables, p. 59-80. In: H.T. Hartmann (ed.). World vegetables: Principles, production, and nutritive values. Chapman and Hall, New York. Sandquist, D.R. 2014. Plants in deserts, 297-326. In: R. Monson (ed.). Ecology and the environment. The plant sciences. Vol. 8. Springer, New York, NY. 
SAS Institute. 2013. The SAS system for Windows. Release 9.4. SAS Institute Inc., Cary, NC.

Thies, J.A. and A. Levi. 2007. Characterization of watermelon (Citrullus lanatus var. citroides) germplasm for resistance to root-knot nematodes. HortScience 42:1530-1533.

Thies, J.A., J.J. Ariss, R.L. Hassell, S. Olson, C.S Kousik, and A. Levi. 2010. Grafting for management of southern root-knot nematode, Meloidogyne incognita, in watermelon. Plant Dis. 94:1195-1199.

Trenberth, K.E., A. Dai, G. van der Schrier, P.D. Jones, J. Barichivich, K.R. Briffa, and J. Sheffield. 2014. Global warming and changes in drought. Nat. Clim. Chang. 4:17-22.

Walker, T.S., H.P. Bais, E. Grotewold, and J.M. Vivanco. 2003. Root exudation and rhizosphere biology. Plant Physiol. 132:44-51.
Wang, Q.-J., Y. Yuan, Z. Liao, Y. Jiang, Q. Wang, L. Zhang, S. Gao, F. Wu, M. Li, W. Xie, T. Liu, J. Xu, Y. Liu, X. Feng, and Y. Lu. 2019. Genome-wide association study of 13 traits in maize seedlings under low phosphorus stress. Plant Gene 12:1-13.

Wasson, A.P., R.A. Richards, R. Chatrath, S.C. Misra, S.V. Prasad, G.J. Rebetzke, J.A. Kirkegaard, J. Christopher, and M. Watt. 2012. Traits and selection strategies to improve root systems and water uptake in water limited wheat crops. J. Expt. Bot. 63:3485-3498.

Wechter, W.P., C. Kousik, M. McMillan, and A. Levi. 2012. Identification of resistance to Fusarium oxysporum f. sp. niveum race 2 in Citrullus lanatus var. citroides plant introductions. HortScience 47:334-338.

Wimer, J., D. Inglis, and C. Miles. 2015. Evaluating grafted watermelon for verticillium wilt severity, yield, and fruit quality in Washington state. HortScience 50:1332-1337.

Yan, W. and J. Fregeau-Reid. 2008. Breeding line selection based on multiple traits. Crop Sci. 48:417-423.

Yanyan, Y., S. Wang, M. Wei, B. Gong, and Q. Shi. 2018. Effect of different rootstocks on the salt stress tolerance in watermelon seedlings. Hort. Plant J. 4:239-249.

Zhang, H., G. Gong, S. Guo, Y. Ren, Y. Xu, and K.-S. Ling. 2011. Screening the USDA watermelon germplasm collection for drought tolerance at the seedling stage. HortScience 46: 1245-1248.

Zhu, J., P.A. Ingram, P.N. Benfey, and T. Elich. 2011. From lab to field, new approaches to phenotyping root system architecture. Curr. Opin. Plant Biol 14:310-317. 
Supplemental Table 1. Evaluation of root traits performance across the 335 Citrullus sp. accessions grown under greenhouse conditions.

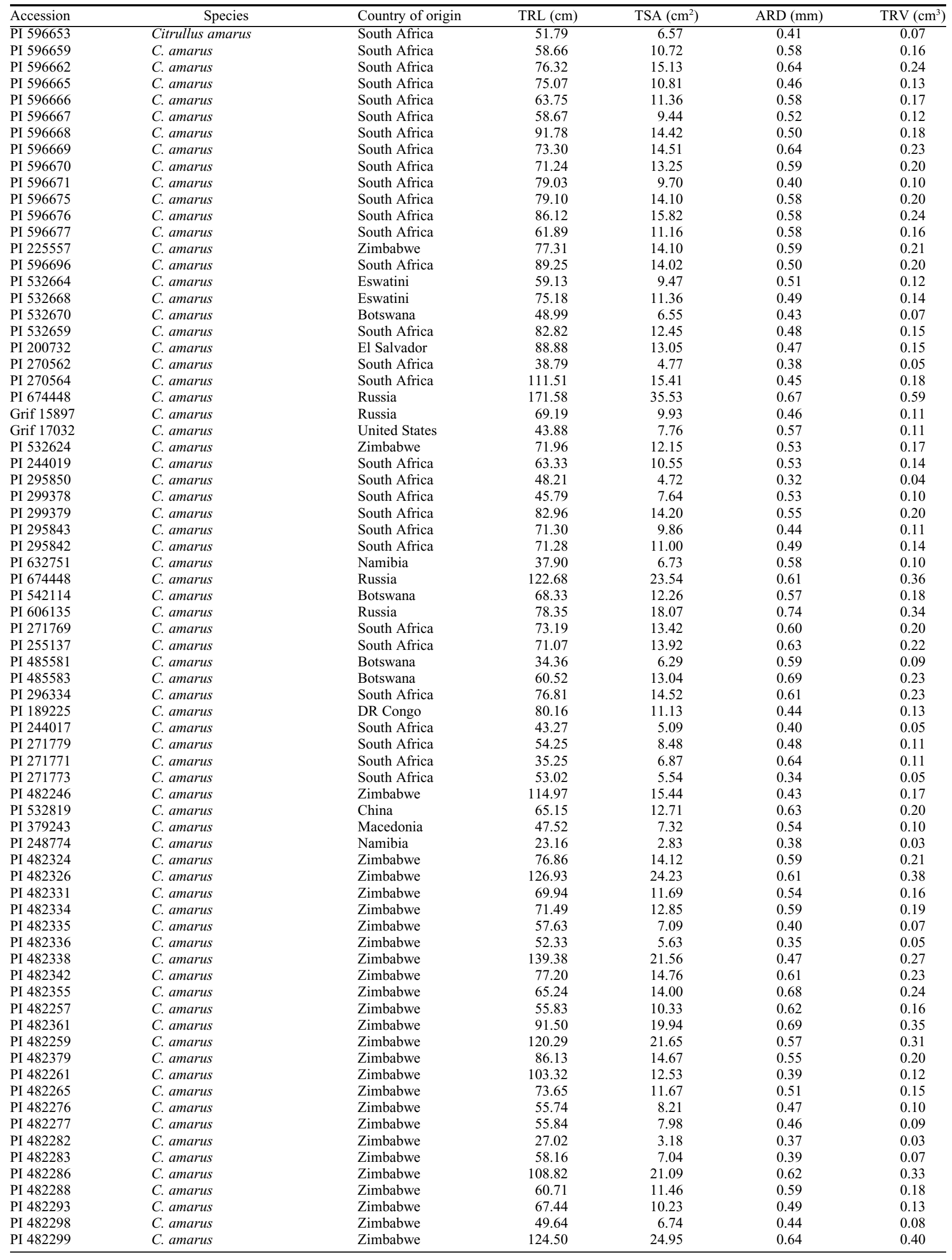


Supplemental Table 1. (Continued) Evaluation of root traits performance across the 335 Citrullus sp. accessions grown under greenhouse conditions.

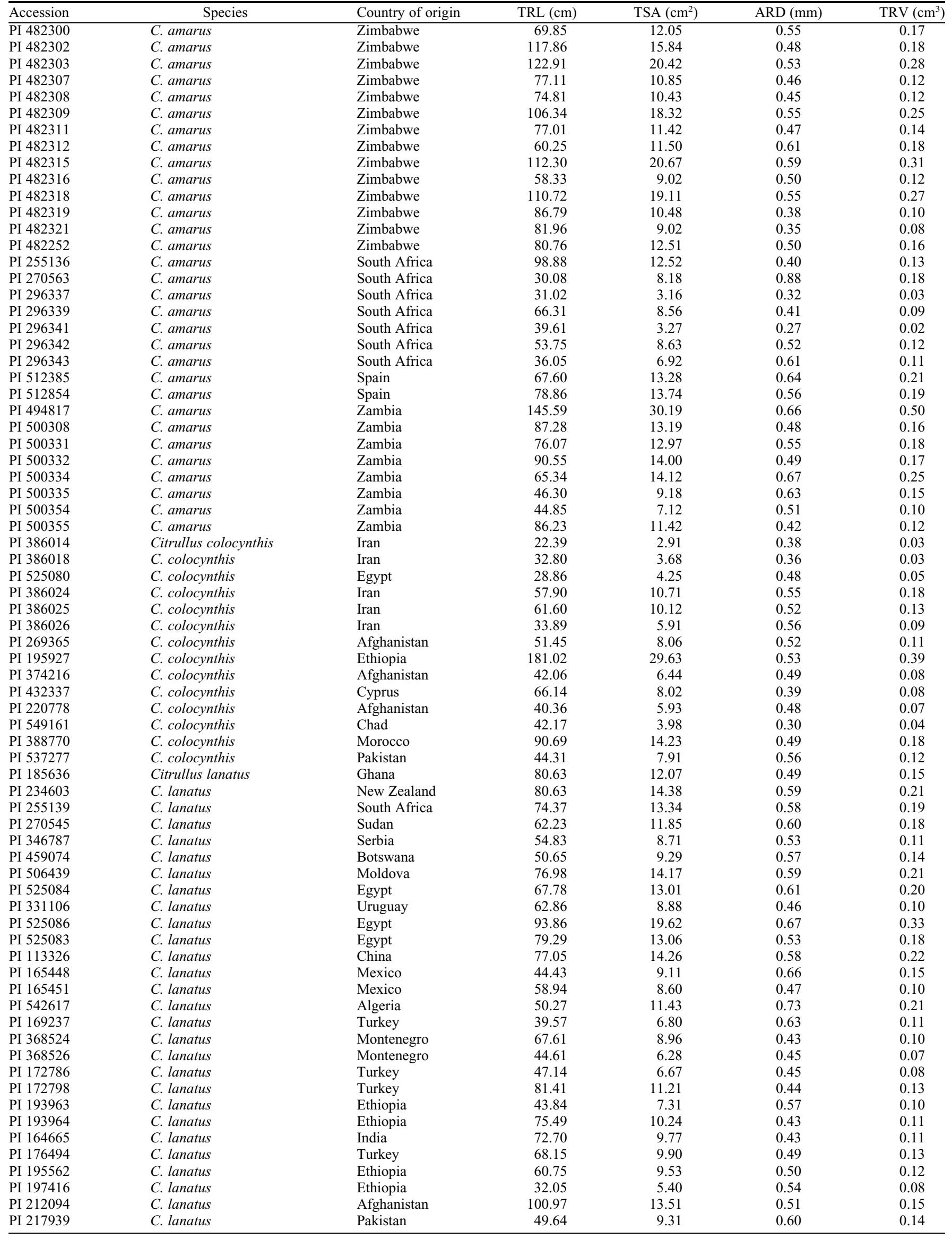


Supplemental Table 1. (Continued) Evaluation of root traits performance across the 335 Citrullus sp. accessions grown under greenhouse conditions.

\begin{tabular}{|c|c|c|c|c|c|c|}
\hline Accession & Species & Country of origin & TRL (cm) & TSA $\left(\mathrm{cm}^{2}\right)$ & $\mathrm{ARD}(\mathrm{mm})$ & $\operatorname{TRV}\left(\mathrm{cm}^{3}\right)$ \\
\hline$\overline{\text { PI } 219691}$ & C. lanatus & Pakistan & 49.68 & 8.43 & 0.56 & 0.12 \\
\hline PI 253174 & C. lanatus & Serbia & 31.51 & 6.35 & 0.65 & 0.11 \\
\hline PI 246559 & C. lanatus & Senegal & 25.76 & 3.59 & 0.43 & 0.04 \\
\hline PI 507867 & C. lanatus & Hungary & 32.26 & 6.04 & 0.61 & 0.09 \\
\hline PI 249010 & C. lanatus & Nigeria & 51.41 & 6.12 & 0.38 & 0.06 \\
\hline PI 254744 & C. lanatus & Senegal & 127.53 & 19.97 & 0.50 & 0.25 \\
\hline PI 181742 & C. lanatus & Lebanon & 59.99 & 10.89 & 0.58 & 0.16 \\
\hline PI 181868 & C. lanatus & Syria & 69.92 & 11.77 & 0.53 & 0.16 \\
\hline Allsweet & C. lanatus & United States & 15.18 & 2.56 & 0.55 & 0.04 \\
\hline PI 526238 & C. lanatus & Zimbabwe & 47.09 & 8.61 & 0.59 & 0.13 \\
\hline PI 526233 & C. lanatus & Zimbabwe & 55.61 & 8.03 & 0.46 & 0.10 \\
\hline PI 512398 & C. lanatus & Spain & 115.10 & 17.72 & 0.49 & 0.22 \\
\hline PI 512404 & C. lanatus & Spain & 45.11 & 8.44 & 0.60 & 0.13 \\
\hline PI 270144 & C. lanatus & Greece & 65.39 & 10.25 & 0.50 & 0.13 \\
\hline PI 193490 & C. lanatus & Ethiopia & 73.56 & 12.43 & 0.54 & 0.17 \\
\hline PI 227203 & C. lanatus & Japan & 63.62 & 10.95 & 0.55 & 0.16 \\
\hline PI 518606 & C. lanatus & Russia & 34.22 & 5.80 & 0.53 & 0.08 \\
\hline PI 556995 & C. lanatus & United States & 43.39 & 6.33 & 0.47 & 0.08 \\
\hline PI 601062 & C. lanatus & United States & 39.55 & 6.82 & 0.57 & 0.10 \\
\hline PI 635586 & C. lanatus & United States & 58.94 & 10.23 & 0.55 & 0.14 \\
\hline PI 179233 & C. lanatus & Turkey & 36.79 & 6.21 & 0.54 & 0.08 \\
\hline PI 635713 & C. lanatus & United States & 16.05 & 3.81 & 0.82 & 0.08 \\
\hline PI 271985 & C. lanatus & Somalia & 39.94 & 7.47 & 0.62 & 0.12 \\
\hline PI 635642 & C. lanatus & United States & 43.69 & 7.60 & 0.56 & 0.11 \\
\hline PI 385964 & C. lanatus & Kenya & 49.47 & 7.56 & 0.49 & 0.09 \\
\hline PI 635688 & C. lanatus & United States & 54.44 & 7.76 & 0.45 & 0.09 \\
\hline PI 357656 & C. lanatus & Macedonia & 40.68 & 7.94 & 0.67 & 0.13 \\
\hline PI 512332 & C. lanatus & China & 44.55 & 7.96 & 0.59 & 0.12 \\
\hline PI 635691 & C. lanatus & United States & 137.20 & 19.28 & 0.45 & 0.22 \\
\hline PI 612464 & C. lanatus & Korea, South & 56.27 & 8.16 & 0.48 & 0.10 \\
\hline PI 612145 & C. lanatus & United States & 34.00 & 5.71 & 0.54 & 0.08 \\
\hline PI 635731 & C. lanatus & United States & 56.17 & 8.95 & 0.51 & 0.11 \\
\hline PI 296332 & C. lanatus & South Africa & 66.92 & 9.82 & 0.46 & 0.13 \\
\hline PI 269677 & C. lanatus & Belize & 27.92 & 5.52 & 2.15 & 0.41 \\
\hline PI 288232 & C. lanatus & Egypt & 42.70 & 7.61 & 0.57 & 0.11 \\
\hline PI 593346 & C. lanatus & China & 45.88 & 6.76 & 0.47 & 0.08 \\
\hline PI 635596 & C. lanatus & United States & 9.36 & 2.04 & 0.74 & 0.04 \\
\hline PI 525098 & C. lanatus & Egypt & 61.85 & 10.45 & 0.54 & 0.15 \\
\hline PI 629108 & C. lanatus & United States & 35.65 & 7.47 & 0.67 & 0.13 \\
\hline PI 192937 & C. lanatus & China & 52.48 & 7.65 & 0.47 & 0.09 \\
\hline Grif 1734 & C. lanatus & China & 30.07 & 5.87 & 0.62 & 0.10 \\
\hline PI 635600 & C. lanatus & United States & 88.68 & 13.35 & 0.48 & 0.16 \\
\hline PI 226459 & C. lanatus & Iran & 62.26 & 10.03 & 0.52 & 0.13 \\
\hline PI 635603 & C. lanatus & United States & 80.18 & 14.13 & 0.56 & 0.20 \\
\hline PI 635741 & C. lanatus & United States & 40.83 & 6.40 & 0.50 & 0.08 \\
\hline PI 276445 & C. lanatus & Jordan & 23.29 & 5.11 & 0.76 & 0.10 \\
\hline PI 438677 & C. lanatus & Mexico & 98.69 & 17.92 & 0.58 & 0.27 \\
\hline PI 179881 & C. lanatus & India & 57.96 & 9.91 & 0.55 & 0.14 \\
\hline PI 490375 & C. lanatus & Mali & 123.16 & 17.28 & 0.45 & 0.20 \\
\hline PI 635606 & C. lanatus & United States & 26.38 & 4.53 & 0.57 & 0.06 \\
\hline PI 536449 & C. lanatus & Maldives & 47.59 & 8.46 & 0.57 & 0.12 \\
\hline PI 536459 & C. lanatus & Maldives & 80.32 & 12.91 & 0.51 & 0.17 \\
\hline PI 536464 & C. lanatus & Maldives & 70.47 & 11.62 & 0.53 & 0.16 \\
\hline PI 635609 & C. lanatus & United States & 40.04 & 5.97 & 0.52 & 0.07 \\
\hline PI 635703 & C. lanatus & United States & 35.58 & 7.21 & 0.70 & 0.12 \\
\hline PI 635614 & C. lanatus & United States & 18.25 & 2.99 & 0.59 & 0.04 \\
\hline PI 180426 & C. lanatus & India & 58.34 & 8.82 & 0.49 & 0.11 \\
\hline PI 169290 & C. lanatus & Turkey & 47.50 & 6.23 & 0.42 & 0.07 \\
\hline PI 532813 & C. lanatus & China & 68.76 & 11.94 & 0.56 & 0.17 \\
\hline PI 601101 & C. lanatus & United States & 55.55 & 10.63 & 0.59 & 0.17 \\
\hline PI 228238 & C. lanatus & Israel & 52.17 & 7.22 & 0.44 & 0.08 \\
\hline PI 270525 & C. lanatus & Israel & 74.33 & 11.28 & 0.52 & 0.15 \\
\hline PI 487476 & C. lanatus & Israel & 45.48 & 8.14 & 0.57 & 0.12 \\
\hline PI 226445 & C. lanatus & Israel & 76.90 & 11.24 & 0.47 & 0.13 \\
\hline PI 635616 & C. lanatus & United States & 46.40 & 7.54 & 0.52 & 0.10 \\
\hline PI 179878 & C. lanatus & India & 59.17 & 8.08 & 0.45 & 0.09 \\
\hline PI 254716 & C. lanatus & Sudan & 48.36 & 7.49 & 0.49 & 0.09 \\
\hline PI 345544 & C. lanatus & Ukraine & 42.57 & 7.06 & 0.55 & 0.10 \\
\hline PI 162667 & C. lanatus & Argentina & 31.38 & 3.62 & 0.37 & 0.04 \\
\hline PI 635630 & C. lanatus & United States & 62.96 & 9.37 & 0.47 & 0.11 \\
\hline PI 601307 & C. lanatus & United States & 26.43 & 4.20 & 0.57 & 0.06 \\
\hline PI 601308 & C. lanatus & United States & 23.92 & 4.50 & 0.64 & 0.07 \\
\hline PI 675114 & C. lanatus & United States & 39.35 & 7.29 & 0.58 & 0.11 \\
\hline
\end{tabular}


Supplemental Table 1. (Continued) Evaluation of root traits performance across the 335 Citrullus sp. accessions grown under greenhouse conditions.

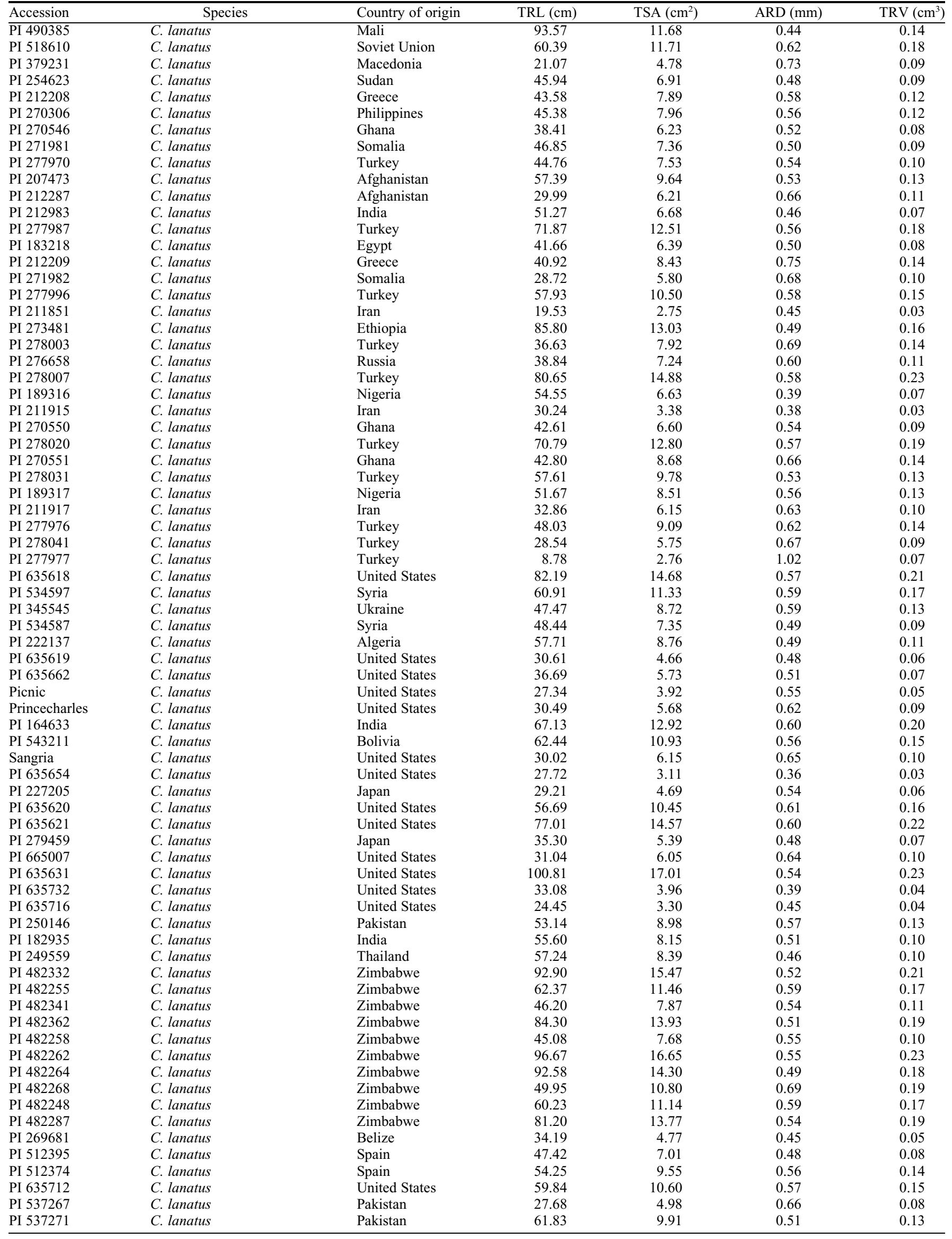


Supplemental Table 1. (Continued) Evaluation of root traits performance across the 335 Citrullus sp. accessions grown under greenhouse conditions.

\begin{tabular}{|c|c|c|c|c|c|c|}
\hline Accession & Species & Country of origin & TRL $(\mathrm{cm})$ & $\operatorname{TSA}\left(\mathrm{cm}^{2}\right)$ & $\mathrm{ARD}(\mathrm{mm})$ & $\operatorname{TRV}\left(\mathrm{cm}^{3}\right)$ \\
\hline$\overline{\text { PI } 381734}$ & C. lanatus & India & 78.76 & 8.38 & 0.34 & 0.07 \\
\hline PI 179234 & C. lanatus & Turkey & 81.39 & 11.19 & 0.44 & 0.13 \\
\hline PI 505586 & C. lanatus & Zambia & 56.07 & 10.14 & 0.57 & 0.15 \\
\hline PI 500301 & C. lanatus & Zambia & 56.47 & 6.85 & 0.40 & 0.07 \\
\hline PI 500314 & C. lanatus & Zambia & 62.69 & 11.70 & 0.61 & 0.18 \\
\hline PI 500319 & C. lanatus & Zambia & 114.72 & 19.48 & 0.55 & 0.27 \\
\hline PI 500328 & C. lanatus & Zambia & 60.68 & 9.87 & 0.53 & 0.13 \\
\hline PI 500344 & C. lanatus & Zambia & 42.33 & 7.60 & 0.58 & 0.11 \\
\hline PI 500350 & C. lanatus & Zambia & 47.27 & 8.20 & 0.56 & 0.12 \\
\hline PI 260733 & C. lanatus & Sudan & 44.75 & 7.15 & 0.54 & 0.10 \\
\hline PI 247398 & Citrullus mucosospermus & Greece & 50.28 & 8.12 & 0.52 & 0.11 \\
\hline PI 164248 & C. mucosospermus & Liberia & 42.92 & 6.49 & 0.49 & 0.08 \\
\hline PI 184800 & C. mucosospermus & Nigeria & 72.25 & 13.61 & 0.62 & 0.21 \\
\hline PI 185635 & C. mucosospermus & Ghana & 52.64 & 5.36 & 0.32 & 0.04 \\
\hline PI 186489 & C. mucosospermus & Nigeria & 64.70 & 8.07 & 0.40 & 0.08 \\
\hline PI 186490 & C. mucosospermus & Nigeria & 139.73 & 26.47 & 0.61 & 0.40 \\
\hline PI 186975 & C. mucosospermus & Ghana & 29.32 & 4.42 & 0.48 & 0.05 \\
\hline PI 189318 & C. mucosospermus & Nigeria & 26.28 & 3.87 & 0.49 & 0.05 \\
\hline PI 249009 & C. mucosospermus & Nigeria & 39.65 & 6.53 & 0.53 & 0.09 \\
\hline PI 254737 & C. mucosospermus & Senegal & 65.58 & 10.23 & 0.50 & 0.13 \\
\hline PI 254740 & C. mucosospermus & Senegal & 50.84 & 7.32 & 0.46 & 0.09 \\
\hline PI 254741 & C. mucosospermus & Senegal & 47.27 & 5.41 & 0.36 & 0.05 \\
\hline PI 254742 & C. mucosospermus & Senegal & 74.65 & 10.55 & 0.45 & 0.12 \\
\hline PI 306782 & C. mucosospermus & Nigeria & 151.36 & 21.83 & 0.46 & 0.26 \\
\hline PI 326516 & C. mucosospermus & Ghana & 46.52 & 9.24 & 0.64 & 0.15 \\
\hline PI 490381 & C. mucosospermus & Mali & 78.67 & 12.91 & 0.52 & 0.17 \\
\hline PI 490386 & C. mucosospermus & Mali & 47.75 & 8.73 & 0.58 & 0.13 \\
\hline PI 494528 & C. mucosospermus & Nigeria & 158.75 & 28.53 & 0.57 & 0.42 \\
\hline PI 494531 & C. mucosospermus & Nigeria & 116.74 & 19.06 & 0.52 & 0.25 \\
\hline PI 532738 & C. mucosospermus & DR Congo & 46.67 & 9.77 & 0.71 & 0.17 \\
\hline PI 559996 & C. mucosospermus & Nigeria & 95.11 & 17.45 & 0.60 & 0.26 \\
\hline PI 560001 & C. mucosospermus & Nigeria & 69.76 & 15.63 & 0.70 & 0.29 \\
\hline PI 560002 & C. mucosospermus & Nigeria & 120.03 & 23.57 & 0.63 & 0.37 \\
\hline PI 560003 & C. mucosospermus & Nigeria & 85.90 & 16.30 & 0.61 & 0.25 \\
\hline PI 560004 & C. mucosospermus & Nigeria & 124.60 & 23.69 & 0.61 & 0.36 \\
\hline PI 560005 & C. mucosospermus & Nigeria & 86.82 & 13.36 & 0.49 & 0.16 \\
\hline PI 560006 & C. mucosospermus & Nigeria & 63.36 & 10.87 & 0.55 & 0.15 \\
\hline PI 560008 & C. mucosospermus & Nigeria & 71.04 & 11.86 & 0.53 & 0.16 \\
\hline PI 560010 & C. mucosospermus & Nigeria & 70.87 & 11.67 & 0.53 & 0.16 \\
\hline PI 560012 & C. mucosospermus & Nigeria & 93.50 & 19.77 & 0.67 & 0.34 \\
\hline PI 560020 & C. mucosospermus & Nigeria & 52.69 & 6.46 & 0.39 & 0.07 \\
\hline PI 248178 & C. mucosospermus & DR Congo & 46.53 & 5.14 & 0.36 & 0.05 \\
\hline $\operatorname{LSD}(\alpha=0.05)$ & & & 24.38 & 4.19 & 0.29 & 0.09 \\
\hline
\end{tabular}

$\mathrm{TRL}=$ total root length; $\mathrm{TSA}=$ total root surface area; $\mathrm{ARD}=$ average root diameter; $\mathrm{TRV}=$ total root volume; $\mathrm{LSD}=$ least significant difference. 
Supplemental Table 2. Evaluation of root morphological traits within the 0 - to $0.5-\mathrm{mm}$ root diameter size class (secondary roots) across the 335 Citrullus sp. accessions that were grown under greenhouse conditions.

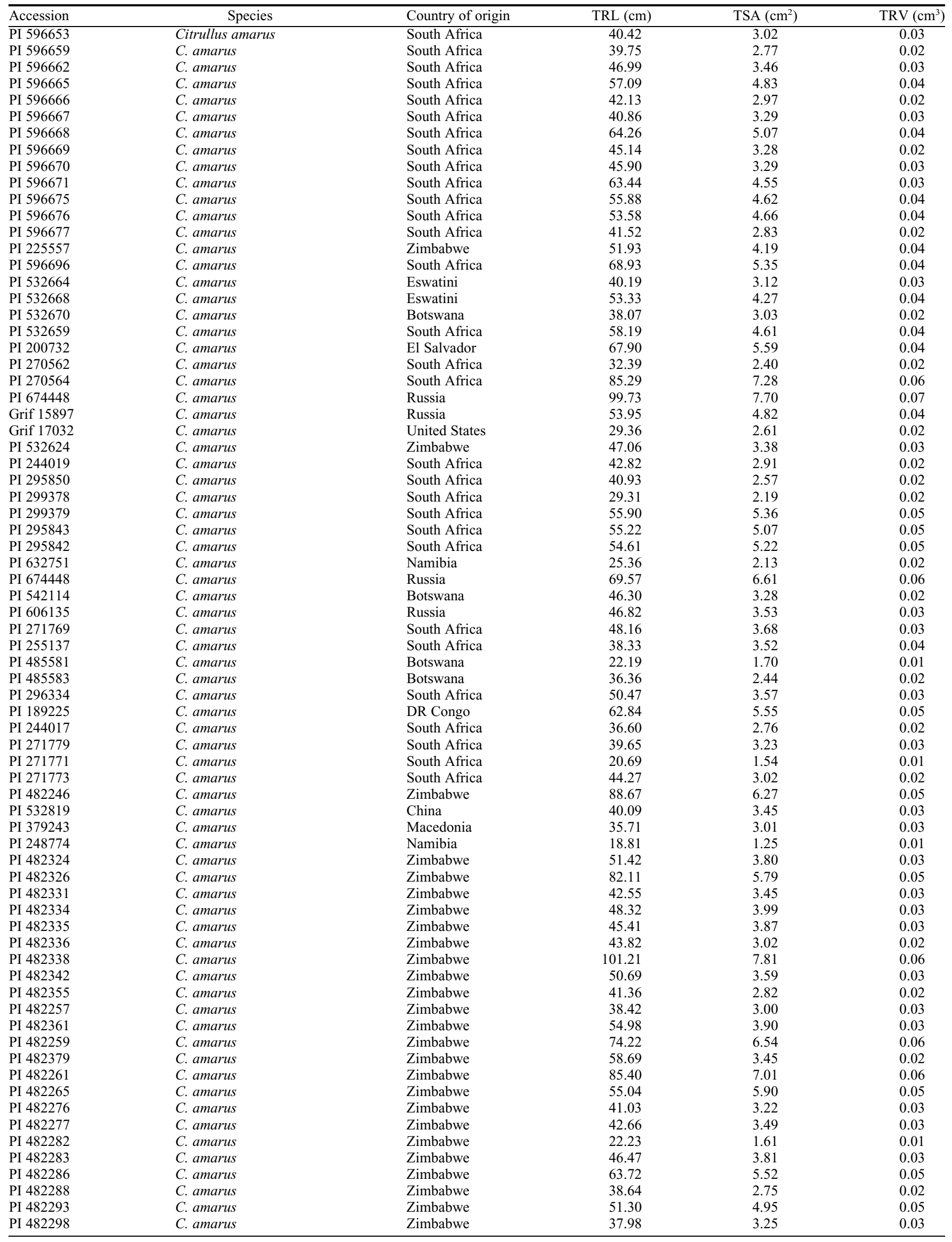


Supplemental Table 2. (Continued) Evaluation of root morphological traits within the 0- to 0.5-mm root diameter size class (secondary roots) across the 335 Citrullus sp. accessions that were grown under greenhouse conditions.

\begin{tabular}{|c|c|c|c|c|c|}
\hline Accession & Species & Country of origin & TRL (cm) & $\operatorname{TSA}\left(\mathrm{cm}^{2}\right)$ & $\operatorname{TRV}\left(\mathrm{cm}^{3}\right)$ \\
\hline$\overline{\text { PI } 482299}$ & C. amarus & Zimbabwe & 71.87 & 5.15 & 0.04 \\
\hline PI 482300 & C. amarus & Zimbabwe & 40.96 & 4.16 & 0.04 \\
\hline PI 482302 & C. amarus & Zimbabwe & 93.18 & 7.16 & 0.05 \\
\hline PI 482303 & C. amarus & Zimbabwe & 89.58 & 7.24 & 0.06 \\
\hline PI 482307 & C. amarus & Zimbabwe & 60.99 & 5.75 & 0.05 \\
\hline PI 482308 & C. amarus & Zimbabwe & 58.87 & 5.10 & 0.04 \\
\hline PI 482309 & C. amarus & Zimbabwe & 70.64 & 6.01 & 0.05 \\
\hline PI 482311 & C. amarus & Zimbabwe & 57.80 & 5.20 & 0.04 \\
\hline PI 482312 & C. amarus & Zimbabwe & 38.46 & 3.77 & 0.03 \\
\hline PI 482315 & C. amarus & Zimbabwe & 76.12 & 5.39 & 0.04 \\
\hline PI 482316 & C. amarus & Zimbabwe & 40.13 & 3.48 & 0.03 \\
\hline PI 482318 & C. amarus & Zimbabwe & 74.00 & 5.88 & 0.05 \\
\hline PI 482319 & C. amarus & Zimbabwe & 71.46 & 5.95 & 0.05 \\
\hline PI 482321 & C. amarus & Zimbabwe & 69.46 & 5.11 & 0.04 \\
\hline PI 482252 & C. amarus & Zimbabwe & 64.31 & 5.66 & 0.05 \\
\hline PI 255136 & C. amarus & South Africa & 80.69 & 5.76 & 0.04 \\
\hline PI 270563 & C. amarus & South Africa & 16.40 & 1.47 & 0.01 \\
\hline PI 296337 & C. amarus & South Africa & 27.29 & 1.99 & 0.02 \\
\hline PI 296339 & C. amarus & South Africa & 50.46 & 3.38 & 0.03 \\
\hline PI 296341 & C. amarus & South Africa & 36.68 & 2.16 & 0.01 \\
\hline PI 296342 & C. amarus & South Africa & 37.59 & 2.80 & 0.02 \\
\hline PI 296343 & C. amarus & South Africa & 22.76 & 1.51 & 0.01 \\
\hline PI 512385 & C. amarus & Spain & 42.67 & 3.86 & 0.03 \\
\hline PI 512854 & C. amarus & Spain & 52.26 & 4.98 & 0.05 \\
\hline PI 494817 & C. amarus & Zambia & 94.43 & 6.37 & 0.05 \\
\hline PI 500308 & C. amarus & Zambia & 66.52 & 6.02 & 0.05 \\
\hline PI 500331 & C. amarus & Zambia & 52.59 & 3.06 & 0.03 \\
\hline PI 500332 & C. amarus & Zambia & 64.26 & 5.50 & 0.05 \\
\hline PI 500334 & C. amarus & Zambia & 41.18 & 3.51 & 0.03 \\
\hline PI 500335 & C. amarus & Zambia & 26.67 & 2.25 & 0.02 \\
\hline PI 500354 & C. amarus & Zambia & 31.43 & 2.44 & 0.02 \\
\hline PI 500355 & C. amarus & Zambia & 67.97 & 5.29 & 0.04 \\
\hline PI 386014 & Citrullus colocynthis & Iran & 16.53 & 1.10 & 0.01 \\
\hline PI 386018 & C. colocynthis & Iran & 25.19 & 1.28 & 0.01 \\
\hline PI 525080 & C. colocynthis & Egypt & 19.68 & 1.37 & 0.01 \\
\hline PI 386024 & C. colocynthis & Iran & 39.66 & 3.01 & 0.02 \\
\hline PI 386025 & C. colocynthis & Iran & 42.05 & 2.86 & 0.02 \\
\hline PI 386026 & C. colocynthis & Iran & 21.99 & 1.80 & 0.02 \\
\hline PI 269365 & C. colocynthis & Afghanistan & 35.93 & 2.87 & 0.02 \\
\hline PI 195927 & C. colocynthis & Ethiopia & 127.30 & 8.95 & 0.07 \\
\hline PI 374216 & C. colocynthis & Afghanistan & 30.22 & 2.32 & 0.02 \\
\hline PI 432337 & C. colocynthis & Cyprus & 52.78 & 3.66 & 0.03 \\
\hline PI 220778 & C. colocynthis & Afghanistan & 29.06 & 2.39 & 0.02 \\
\hline PI 549161 & C. colocynthis & Chad & 36.47 & 2.15 & 0.01 \\
\hline PI 388770 & C. colocynthis & Morocco & 64.47 & 4.51 & 0.04 \\
\hline PI 537277 & C. colocynthis & Pakistan & 29.53 & 2.31 & 0.02 \\
\hline PI 185636 & Citrullus lanatus & Ghana & 58.99 & 4.43 & 0.04 \\
\hline PI 234603 & C. lanatus & New Zealand & 51.00 & 3.96 & 0.03 \\
\hline PI 255139 & C. lanatus & South Africa & 47.31 & 4.90 & 0.04 \\
\hline PI 270545 & C. lanatus & Sudan & 36.10 & 2.94 & 0.03 \\
\hline PI 346787 & C. lanatus & Serbia & 39.94 & 3.51 & 0.03 \\
\hline PI 459074 & C. lanatus & Botswana & 34.62 & 2.31 & 0.02 \\
\hline PI 506439 & C. lanatus & Moldova & 53.10 & 5.46 & 0.05 \\
\hline PI 525084 & C. lanatus & Egypt & 46.00 & 4.71 & 0.04 \\
\hline PI 331106 & C. lanatus & Uruguay & 50.91 & 4.22 & 0.03 \\
\hline PI 525086 & C. lanatus & Egypt & 51.45 & 5.23 & 0.05 \\
\hline PI 525083 & C. lanatus & Egypt & 57.12 & 4.42 & 0.04 \\
\hline PI 113326 & C. lanatus & China & 51.93 & 3.82 & 0.03 \\
\hline PI 165448 & C. lanatus & Mexico & 27.55 & 2.01 & 0.02 \\
\hline PI 165451 & C. lanatus & Mexico & 43.46 & 3.38 & 0.03 \\
\hline PI 542617 & C. lanatus & Algeria & 32.26 & 3.52 & 0.03 \\
\hline PI 169237 & C. lanatus & Turkey & 28.21 & 2.28 & 0.02 \\
\hline PI 368524 & C. lanatus & Montenegro & 50.31 & 3.36 & 0.02 \\
\hline PI 368526 & C. lanatus & Montenegro & 34.93 & 2.73 & 0.02 \\
\hline PI 172786 & C. lanatus & Turkey & 36.65 & 2.65 & 0.02 \\
\hline PI 172798 & C. lanatus & Turkey & 62.58 & 4.55 & 0.03 \\
\hline PI 193963 & C. lanatus & Ethiopia & 30.10 & 2.46 & 0.02 \\
\hline PI 193964 & C. lanatus & Ethiopia & 59.66 & 4.88 & 0.04 \\
\hline PI 164665 & C. lanatus & India & 56.22 & 4.02 & 0.03 \\
\hline PI 176494 & C. lanatus & Turkey & 51.85 & 3.46 & 0.03 \\
\hline PI 195562 & C. lanatus & Ethiopia & 44.68 & 3.78 & 0.03 \\
\hline PI 197416 & C. lanatus & Ethiopia & 21.63 & 1.74 & 0.01 \\
\hline PI 212094 & C. lanatus & Afghanistan & 81.32 & 6.66 & 0.05 \\
\hline
\end{tabular}


Supplemental Table 2. (Continued) Evaluation of root morphological traits within the 0 - to 0.5 -mm root diameter size class (secondary roots) across the 335 Citrullus sp. accessions that were grown under greenhouse conditions.

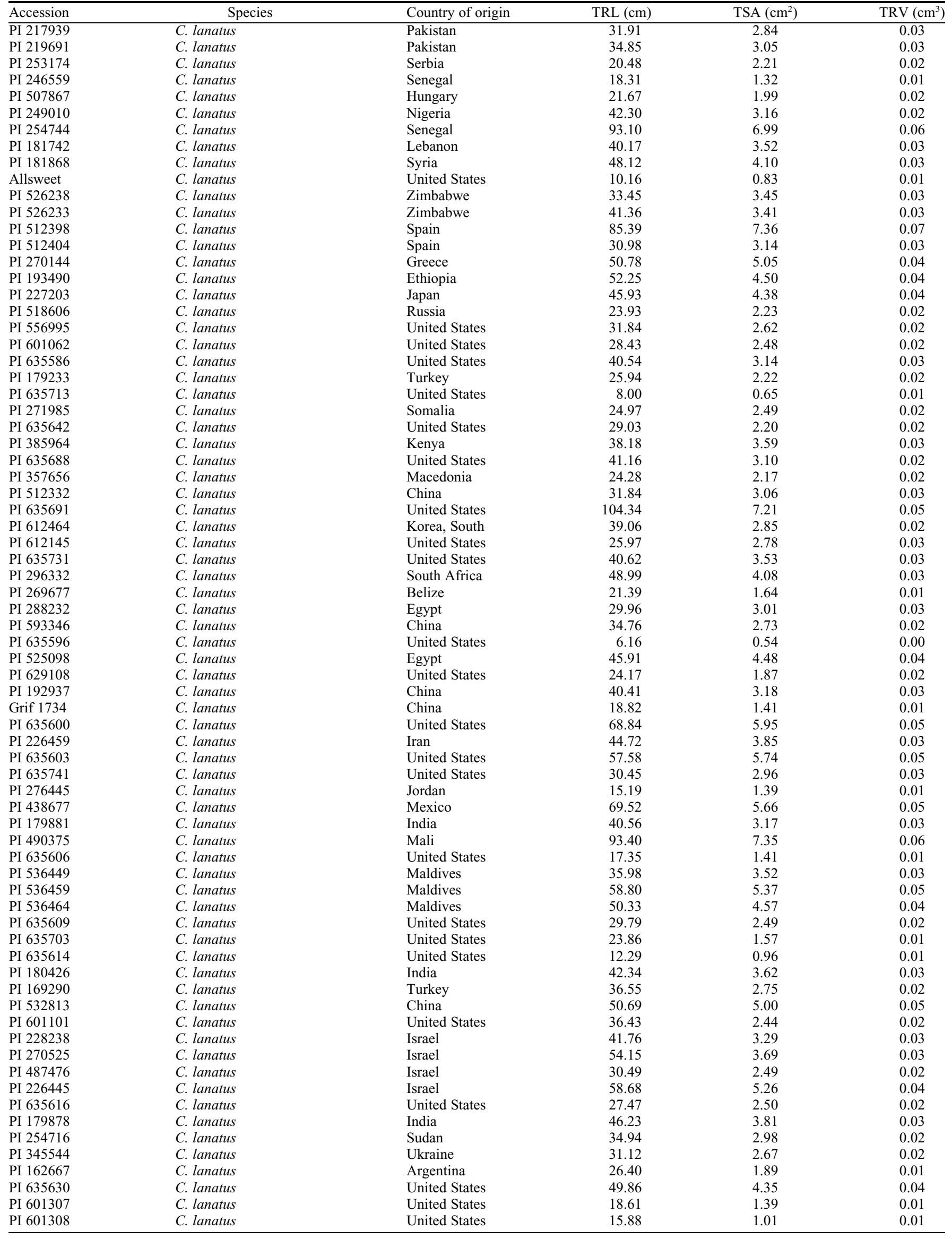


Supplemental Table 2. (Continued) Evaluation of root morphological traits within the 0- to 0.5-mm root diameter size class (secondary roots) across the 335 Citrullus sp. accessions that were grown under greenhouse conditions.

\begin{tabular}{|c|c|c|c|c|c|}
\hline$\overline{\text { Accession }}$ & Species & Country of origin & TRL (cm) & $\operatorname{TSA}\left(\mathrm{cm}^{2}\right)$ & $\operatorname{TRV}\left(\mathrm{cm}^{3}\right)$ \\
\hline$\overline{\text { PI } 675114}$ & C. lanatus & United States & 24.81 & 1.80 & 0.01 \\
\hline PI 490385 & C. lanatus & Mali & 77.91 & 4.73 & 0.03 \\
\hline PI 518610 & C. lanatus & Soviet Union & 41.17 & 3.88 & 0.03 \\
\hline PI 379231 & C. lanatus & Macedonia & 9.36 & 0.98 & 0.01 \\
\hline PI 254623 & C. lanatus & Sudan & 35.54 & 3.28 & 0.03 \\
\hline PI 212208 & C. lanatus & Greece & 28.79 & 2.70 & 0.03 \\
\hline PI 270306 & C. lanatus & Philippines & 33.73 & 3.56 & 0.03 \\
\hline PI 270546 & C. lanatus & Ghana & 28.60 & 2.76 & 0.02 \\
\hline PI 271981 & C. lanatus & Somalia & 34.27 & 3.04 & 0.03 \\
\hline PI 277970 & C. lanatus & Turkey & 32.63 & 3.14 & 0.03 \\
\hline PI 207473 & C. lanatus & Afghanistan & 42.12 & 3.57 & 0.03 \\
\hline PI 212287 & C. lanatus & Afghanistan & 18.64 & 1.71 & 0.01 \\
\hline PI 212983 & C. lanatus & India & 40.37 & 2.96 & 0.02 \\
\hline PI 277987 & C. lanatus & Turkey & 51.44 & 5.04 & 0.04 \\
\hline PI 183218 & C. lanatus & Egypt & 30.90 & 2.50 & 0.02 \\
\hline PI 212209 & C. lanatus & Greece & 23.71 & 2.23 & 0.02 \\
\hline PI 271982 & C. lanatus & Somalia & 17.53 & 1.86 & 0.02 \\
\hline PI 277996 & C. lanatus & Turkey & 38.65 & 4.23 & 0.04 \\
\hline PI 211851 & C. lanatus & Iran & 15.32 & 1.30 & 0.01 \\
\hline PI 273481 & C. lanatus & Ethiopia & 65.01 & 5.96 & 0.05 \\
\hline PI 278003 & C. lanatus & Turkey & 24.07 & 2.05 & 0.02 \\
\hline PI 276658 & C. lanatus & Russia & 25.89 & 2.62 & 0.02 \\
\hline PI 278007 & C. lanatus & Turkey & 54.09 & 5.64 & 0.05 \\
\hline PI 189316 & C. lanatus & Nigeria & 44.06 & 3.38 & 0.02 \\
\hline PI 211915 & C. lanatus & Iran & 24.65 & 1.67 & 0.01 \\
\hline PI 270550 & C. lanatus & Ghana & 31.49 & 2.51 & 0.02 \\
\hline PI 278020 & C. lanatus & Turkey & 46.76 & 3.54 & 0.03 \\
\hline PI 270551 & C. lanatus & Ghana & 27.99 & 2.35 & 0.02 \\
\hline PI 278031 & C. lanatus & Turkey & 41.68 & 4.01 & 0.04 \\
\hline PI 189317 & C. lanatus & Nigeria & 33.00 & 2.78 & 0.02 \\
\hline PI 211917 & C. lanatus & Iran & 20.10 & 2.01 & 0.02 \\
\hline PI 277976 & C. lanatus & Turkey & 32.27 & 2.73 & 0.02 \\
\hline PI 278041 & C. lanatus & Turkey & 17.82 & 1.56 & 0.01 \\
\hline PI 277977 & C. lanatus & Turkey & 4.57 & 0.42 & 0.00 \\
\hline PI 635618 & C. lanatus & United States & 55.57 & 6.24 & 0.06 \\
\hline PI 534597 & C. lanatus & Syria & 40.31 & 3.29 & 0.03 \\
\hline PI 345545 & C. lanatus & Ukraine & 28.14 & 2.55 & 0.02 \\
\hline PI 534587 & C. lanatus & Syria & 36.34 & 3.02 & 0.02 \\
\hline PI 222137 & C. lanatus & Algeria & 44.48 & 4.10 & 0.04 \\
\hline PI 635619 & C. lanatus & United States & 23.68 & 2.07 & 0.02 \\
\hline PI 635662 & C. lanatus & United States & 26.66 & 2.35 & 0.02 \\
\hline Picnic & C. lanatus & United States & 22.49 & 1.65 & 0.01 \\
\hline Princecharles & C. lanatus & United States & 19.34 & 1.39 & 0.01 \\
\hline PI 164633 & C. lanatus & India & 45.54 & 3.33 & 0.03 \\
\hline PI 543211 & C. lanatus & Bolivia & 43.25 & 4.33 & 0.04 \\
\hline Sangria & C. lanatus & United States & 18.30 & 1.15 & 0.01 \\
\hline PI 635654 & C. lanatus & United States & 22.31 & 1.41 & 0.01 \\
\hline PI 227205 & C. lanatus & Japan & 21.54 & 1.72 & 0.02 \\
\hline PI 635620 & C. lanatus & United States & 40.00 & 4.12 & 0.04 \\
\hline PI 635621 & C. lanatus & United States & 51.08 & 5.56 & 0.05 \\
\hline PI 279459 & C. lanatus & Japan & 26.96 & 2.72 & 0.02 \\
\hline PI 665007 & C. lanatus & United States & 19.72 & 1.61 & 0.01 \\
\hline PI 635631 & C. lanatus & United States & 73.45 & 6.48 & 0.05 \\
\hline PI 635732 & C. lanatus & United States & 25.22 & 1.49 & 0.01 \\
\hline PI 635716 & C. lanatus & United States & 18.75 & 1.21 & 0.01 \\
\hline PI 250146 & C. lanatus & Pakistan & 34.37 & 2.95 & 0.02 \\
\hline PI 182935 & C. lanatus & India & 41.85 & 3.38 & 0.03 \\
\hline PI 249559 & C. lanatus & Thailand & 42.79 & 3.59 & 0.03 \\
\hline PI 482332 & C. lanatus & Zimbabwe & 65.19 & 5.51 & 0.05 \\
\hline PI 482255 & C. lanatus & Zimbabwe & 41.73 & 2.99 & 0.02 \\
\hline PI 482341 & C. lanatus & Zimbabwe & 30.70 & 2.72 & 0.02 \\
\hline PI 482362 & C. lanatus & Zimbabwe & 59.74 & 4.13 & 0.03 \\
\hline PI 482258 & C. lanatus & Zimbabwe & 30.72 & 2.09 & 0.02 \\
\hline PI 482262 & C. lanatus & Zimbabwe & 69.12 & 6.68 & 0.06 \\
\hline PI 482264 & C. lanatus & Zimbabwe & 65.05 & 5.52 & 0.05 \\
\hline PI 482268 & C. lanatus & Zimbabwe & 31.25 & 2.43 & 0.02 \\
\hline PI 482248 & C. lanatus & Zimbabwe & 40.15 & 2.95 & 0.02 \\
\hline PI 482287 & C. lanatus & Zimbabwe & 58.00 & 5.56 & 0.05 \\
\hline PI 269681 & C. lanatus & Belize & 25.55 & 1.91 & 0.02 \\
\hline PI 512395 & C. lanatus & Spain & 37.91 & 3.20 & 0.03 \\
\hline PI 512374 & C. lanatus & Spain & 36.23 & 2.82 & 0.02 \\
\hline PI 635712 & C. lanatus & United States & 38.59 & 3.62 & 0.03 \\
\hline PI 537267 & C. lanatus & Pakistan & 18.52 & 1.48 & 0.01 \\
\hline
\end{tabular}


Supplemental Table 2. (Continued) Evaluation of root morphological traits within the 0 - to 0.5 -mm root diameter size class (secondary roots) across the 335 Citrullus sp. accessions that were grown under greenhouse conditions.

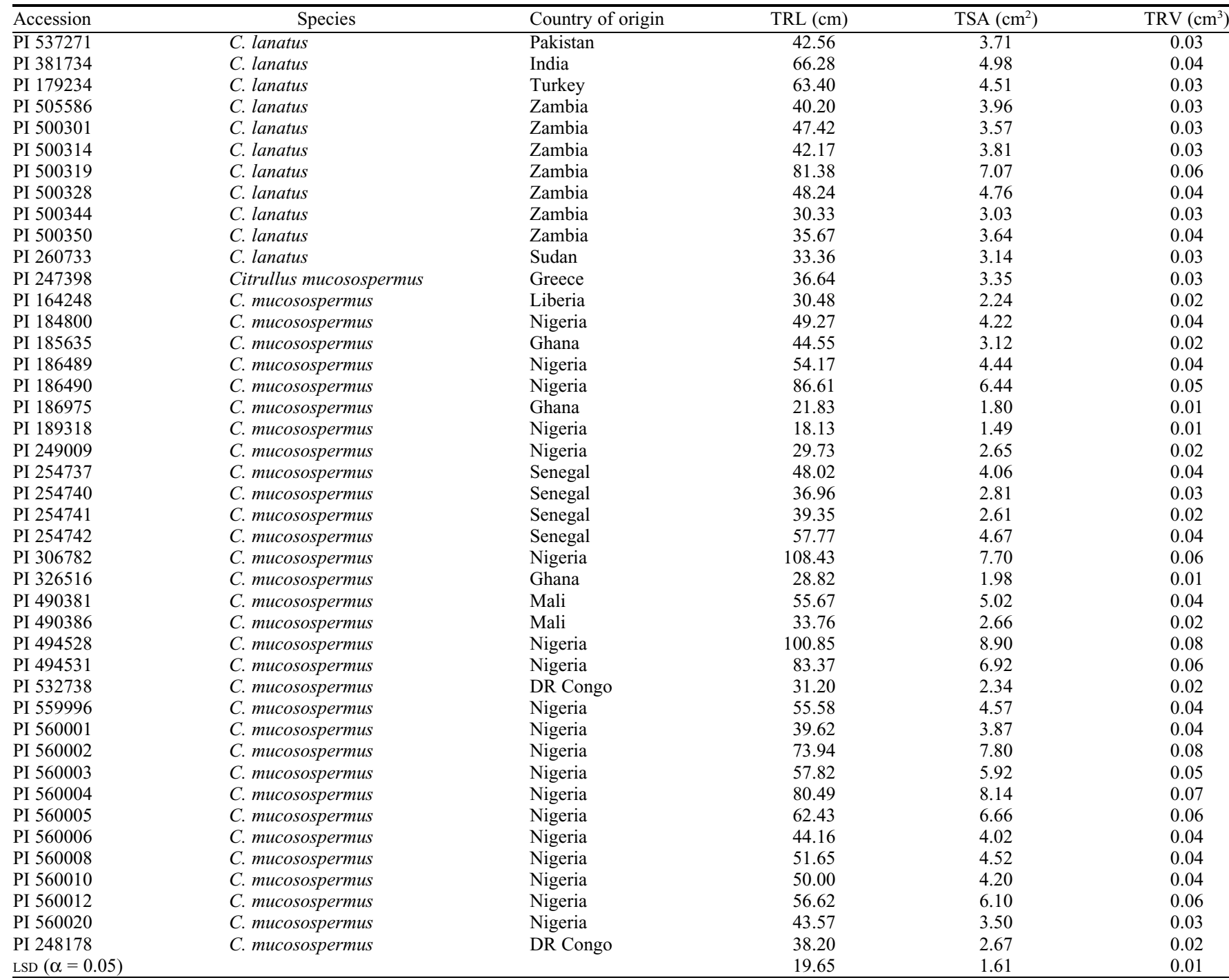

$\mathrm{TRL}=$ total root length; $\mathrm{TSA}=$ total root surface area; $\mathrm{TRV}=$ total root volume; $\mathrm{LSD}=$ least significant difference. 